\title{
Comentario SOBRE la "Propuesta de ANTEPROYECTO DE LEY DE MODIFICACIÓN DEL ‘Código de Comercio' español” EN LA PARTE GENERAL SOBRE CONTRATOS MERCANTILES Y SOBRE PRESCRIPCIÓN Y CADUCIDAD
}

["Comments on the "Proposal for a Bill to Modify the Spanish 'Code of Commerce" Pertaining to the General part on Commercial Contracts and on Time Limits and Limitation Periods"]

\section{Jaime Alcalde Silva*}

Pontificia Universidad Católica de Chile

RESUMEN

En 2006 se publicó en España una Propuesta de Anteproyecto de Ley de modificación del Código de Comercio en la parte general sobre contratos mercantiles, prescripción y caducidad. Paralelamente, la mentada Comisión ha comenzado a elaborar un Proyecto de Código Mercantil. Esto hace suponer que la Propuesta de 2006 no se convertirá en ley, pues la disciplina en ella ofrecida quedará subsumida en aquél. Sin embargo, su estudio es de interés no sólo en lo que respecta al Derecho español, sino para todos los países pertenecientes a la tradición jurídica romano-francesa, y, por ende, también para Chile. El presente trabajo expone el contenido de la Propuesta.
Abstract

In Spain, in 2006, comments on the Proposal for a bill to modify the Code of Commerce pertaining to the general part on commercial contracts and on time limits and limitation periods were published. The referred Commission began, simultaneously, to prepare a Project for a Code of Commerce. This leads us to assume that the 2006 Proposal shall not become a law, since the discipline therein offered shall be included in it. Nonetheless, studying this proposal is interesting not only in relation to the Spanish Law, but also in relation to all the countries that inherited the tradition of the Roman and French legal systems and, consequently, its rela-

* Instructor adjunto de Derecho Civil de la Pontificia Universidad Católica de Chile. Investigador de la Academia de Derecho Privado UC y del Centro de Gobierno Corporativo UC. Dirección postal: Facultad de Derecho, Pontificia Universidad Católica de Chile, Avda. Libertador Bernardo O'Higgins 340, 8320000 Santiago, Chile. Correo electrónico: jcalcald@uc.cl. 
Palabras Clave

Código de Comercio español - Propuesta de modificación del Código de Comercio español. tionship with Chile. This article presents the contents of the Proposal.

KEYWORDS

Spanish Code of Commerce - Proposal to modify the Spanish Code of Commerce.

[RECIBIDo el 2 de noviembre y ACEPTADo el 12 de diciembre de 2011].

\section{Propósito De este Comentario}

El 1 de febrero de 2006 se hizo pública la Propuesta de anteproyecto de ley sobre modificación del Código de Comercio español en la parte general sobre contratos mercantiles y sobre prescripción y caducidad (PACCom.), elaborada por la Sección Segunda (Derecho Mercantil) de la Comisión General de Codificación. De momento, sin embargo, esta Propuesta no se ha convertido en ley, pese a la importancia que sus disposiciones tienen en la modernización del derecho privado que se está emprendiendo, desde distintos frentes, en la Unión Europea. Concretamente, porque las disposiciones contenidas ella permiten remozar la disciplina de los contratos mercantiles contenida en el Código de Comercio de 1885, que la doctrina ha criticado por su carácter fragmentario, incompleto y, sobre todo, obsoleto $^{1}$. A este empeño de actualización se ha sumado, en enero de 2009 , la Propuesta de modernización del Código Civil en materia de obligaciones y contratos, también preparada por la Comisión General de Codificación, y que a diferencia de su símil mercantil ha despertado una mayor atención en la literatura especializada ${ }^{2}$.

${ }^{1}$ Bercovitz Álvarez, Rafael, Propuesta de Anteproyecto de Ley de modificación del Código de Comercio en la parte general sobre contratos mercantiles y sobre prescripción y caducidad, en Revista de Derecho Bancario y Bursátil, 102 (2006), p. 304; ILlesCas Ortiz, Rafael, Un nuevo Código de Comercio para España, en Derecho de los Negocios, 196 (2007), p. 2; Jerez Delgado, Carmen - Pérez García, Máximo Juan, La Comisión General de Codificación y su labor en la modernización del Derecho de obligaciones, en Revista Jurídica de la Universidad Autónoma de Madrid, 19 (2009) 1, p. 169; Olivencia Ruiz, Manuel, Un Código Mercantil del siglo XXI, en Gómez Segade, José Antonio - García VIDAL, Ángel (editores), El Derecho mercantil en el umbral del siglo XXI. Libro Homenaje al Prof. Dr. Carlos Fernández-Nóvoa en su octogésimo cumpleaños (Madrid, Marcial Pons Ediciones Jurídicas y Sociales, 2010), pp. 59-60.

${ }^{2}$ Lit.: Albiez Dohrmann, Klaus Jochen (director), Derecho privado europeo y modernización del Derecho contractual en España (Barcelona, Atelier libros, 2011); ÁNGEL YAGÜEZ, Ricardo, Lealtad en el periodo precontractual (la conducta de las partes en las negociaciones preliminares, según proyectos de Derecho contractual europeo y conforme 
El esfuerzo emprendido por España puede servir de ejemplo para una futura reforma del Código Comercio chileno (1865), cuya data es aún más antigua que el vigente código español. La hora actual puede constituir el momento oportuno para iniciar los esfuerzos enderezados a una reforma de nuestros códigos siguiendo el espíritu de la codificación, esto es, sin descuidar la importancia de una adecuada racionalización del material existente y de una correcta sistematización del resultado del proceso de fijación.

Con todo, el objetivo de este comentario es de proporciones más modestas. Merced de él no se desea elaborar las bases dogmáticas de una futura recodificación del derecho comercial en Chile, sino solamente exponer el contenido de la mentada Propuesta de modernización del Código de Co-

a otros trabajos prelegislativos, en Anuario de Derecho Civil, 63 (2010) 3, pp. 575-636; ARANA DE LA FUENTE, Isabel, Algunas precisiones sobre la reforma de la cláusula penal en la Propuesta de modernización del Código Civil en materia de obligaciones y contratos, en InDret, 4 (2010); Fenoy Picón, Nieves, La modernización del régimen del incumplimiento del contrato: propuestas de la Comisión General de Codificación. Primera parte: aspectos generales. El incumplimiento, en Anuario de Derecho Civil, 63 (2010) 1, pp. 47-136; LA MISMA, El incumplimiento contractual y sus remedios en la Propuesta española de modernización del Código Civil de 2009, en DE la Maza Gazmuri, Ínigo (coordinador), Cuadernos de análisis jurídico. Colección Derecho privado, VII: El incumplimiento contractual. Nuevas perspectivas (Santiago, Ediciones de la Universidad Diego Portales, 2011) [en prensa]; Galicia Aizpurúa, Gorka H., Causa de la obligación frente a causa del contrato en el Código Civil español: una exposición critica (a propósito de la Propuesta de modernización del derecho de obligaciones formulada por la Comisión General de Codificación), en Revista de Derecho Privado, 94 (2010) 11-12, pp. 29-61; García Rubio, María Paz, La responsabilidad precontractual en la propuesta de modificación del derecho de obligaciones y contratos, en Anuario de Derecho Civil, 63 (2010) 4, pp. 1621-1642; Marín García, Ignacio, La cláusula penal en la Propuesta de modernización del Código Civil en materia de obligaciones y contratos, en InDret, 4 (2009); Jerez - Pérez, La Comisión General de Codificación, cit. (n.), pp. 170-178; Rodríguez Marín, Concepción, La Propuesta de Anteproyecto de modernización del Código Civil en materia de obligaciones y contratos. Diferencias y similitudes con el cumplimiento, en Revista del Notariado, 76 (2010), pp. 271-300; Rojo ÁlvarezManzaneda, Carmen, Reflexiones sobre la forma del contrato en la Propuesta del Anteproyecto de Ley de modernización del Código Civil en materia de derechos y obligaciones, en Actualidad Juridica Aranzadi, 785 (2009), pp. 12-14; SAlvador Coderch, Pablo, Alteración de circunstancias en el art. 1213 de la Propuesta de modernización del Código Civil en materia de obligaciones y contratos, en InDret, 4 (2009); SAN Miguel Pradera, Lis Paula, La modernización del derecho de obligaciones y la resolución por incumplimientos en los ordenamientos español y chileno, en DE LA MAZA GAZMURI, Ínigo (coordinador), Cuadernos de análisis jurídico. Colección Derecho privado, VII: El incumplimiento contractual. Nuevas perspectivas (Santiago, Ediciones de la Universidad Diego Portales, 2011) [en prensa]; Vidal Olivares, Álvaro, El incumplimiento y los remedios del acreedor en la Propuesta de modernización del derecho de obligaciones y contratos español, en Revista Chilena de Derecho Privado, 16 (2011), pp. 243-302. 
mercio español, haciendo las referencias que sean oportunas a la posterior Propuesta de modernización del Código Civil (PMCC.), con el deseo de que esta noticia pueda ser de utilidad en una futura reforma de nuestro propio código mercantil. Esta metodología explica, por consiguiente, que en la exposición se siga el orden de dicha Propuesta y que, ahí donde sea pertinente, se establezcan las referencias, comparaciones o divergencias existentes con el derecho chileno. Al final, se ofrece una valoración comparativa de toda la Propuesta.

\section{LA HiSTORIA LEGISLATIVA DE LA "PropUeSTA"}

Desde el seno de la Comisión General de Codificación ${ }^{3}$, España ha emprendido en los últimos años dos esfuerzos de modernización de su derecho de obligaciones, cada uno de ellos dedicado a una de las parcelas en las que tradicionalmente se ha dividido el derecho privado: el derecho mercantil y el derecho civil. Tal proceder no sólo se aleja de la idea de unificación en materia contractual a la que se endereza la tendencia comparada y comunitaria (y también parcialmente asumida por España con la Ley $\mathrm{N}^{\circ} 50 / 1980$, de 8 de octubre, sobre contrato de seguro), sino que, además, ahonda la separación entre los contratos civiles y mercantiles, como si se tratase de dos universos dogmáticos distintos ${ }^{4}$.

Originalmente, la idea de la Sección Mercantil de dicha Comisión era aproximar la legislación civil y mercantil en materia de derecho contractual. Para cumplir ese propósito, todo el ámbito de las obligaciones y contratos pasaría a ser objeto del Código Civil, y el Código de Comercio, si alguna vez se rehacía, contendría sólo la regulación del derecho de sociedades, el estatuto jurídico del comerciante o empresario individual de comercio, el derecho de los títulos valores y el derecho concursal ${ }^{5}$. Concretamente, se buscaba

${ }^{3}$ Sobre ella y su labor, véase: Jerez Delgado - Pérez García, La Comisión General de Codificación, cit. (n. 1), pp. 158-165.

${ }^{4}$ Martínez Sanz, Fernando, ¿Derecho contractual europeo y dualidad Código Civil-Código de Comercio?, en Bosch Capdevilla, Esteve (director), Derecho contractual europeo. Problemática, propuestas y perspectivas (Barcelona, Editorial Bosch, 2009), p. 519.

${ }^{5}$ La disposición final trigésima tercera de la Ley concursal (Ley N ${ }^{\circ} 22 / 2003$, de 9 de julio) encomendó al gobierno que remitiera a las Cortes Generales un proyecto de ley reguladora de la concurrencia y prelación de créditos en las ejecuciones singulares. En una primera instancia, tal cometido fue cumplido por la Comisión General de Codificación a través de la Propuesta de anteproyecto de ley de modificación de los capitulos II y III del titulo XVII del libro IV del Código Civil, publicado en el Boletín de Información del Ministerio de Justicia, 1988 (2005), pp. 2092-2097. El Proyecto de Ley de 21 de julio de 2006, en materia de concurrencia y prelación de créditos en el caso de ejecución sin- 
iniciar esta aproximación mediante una regulación unitaria del contrato de compraventa que se correspondiese con el modelo de la Convención de Viena sobre compraventa internacional de mercaderías (CISG), ratificada por España a través del Instrumento de adhesión de 17 de junio de 1990.

La Sección Civil prefirió seguir otro camino, y fue así como desde 1995 comenzó a trabajar en una modernización general del derecho de obligaciones, pero empezando por el artículo $1088 \mathrm{CC}$. (que sirve de pórtico al libro III dedicado a las obligaciones y contratos) y no por la compraventa ${ }^{6}$. Esta elección supuso abandonar la línea de trabajo antes adoptada, a la que adscribía el Anteproyecto de ley por la que se modifica la regulación del Código Civil sobre los contratos de servicio y de obra, de 24 de noviembre de 1993, que finalmente no se convirtió en ley ${ }^{7}$. Con todo, la idea de reformar la disciplina del contrato de compraventa fue posteriormente retomada, y en 2005 se publicó la Propuesta de Anteproyecto de Ley de modificación del Código Civil en materia de contrato de compraventa ${ }^{8}$, inspirada en la CISG; la Directiva N ${ }^{\circ}$ 1999/44/CE del Parlamento Europeo y del Consejo, de 25 de mayo de 1999, sobre determinados aspectos de la venta y las garantías de los bienes de consumo', y los Principios de Derecho europeo de contratos $(\text { PECL. })^{10}$.

Por su parte, la Sección Mercantil volvió sobre su iniciativa original de aproximar la legislación civil y mercantil, pero no lo hizo a través de una unificación cabal del derecho de obligaciones. La matriz utilizada para tal cometido consistió en remozar la disciplina de la parte general del contrato

gular, presentado en el Parlamento, no recogió las líneas matrices de dicha Propuesta, aunque de su lectura se puede comprobar que ésta no fue completamente ignorada. Debido a las críticas negativas que este proyecto recibió por parte de la doctrina, no llegó a convertirse en ley por disolución de las Cortes [Jerez Delgado - Pérez García, La Comisión General de Codificación, cit. (n. 1), p. 168].

${ }^{6}$ Díez-Picazo y Ponce de León, Luis, Reforma de los códigos y Derecho europeo, en Anuario de Derecho Civil, 56 (2003) 4, pp. 1567-1568.

${ }^{7}$ Este Anteproyecto modificaba los artículos 1542-1544, 1593-1600 y 1603 del Código Civil, además de derogar los artículos 1545 y 1546 de ese mismo código y de introducir una nueva distribución de materias para sistematizar los contratos de obra y de servicio.

${ }^{8}$ Publicada en Boletín de Información del Ministerio de Justicia, 1988 (2005), pp. 2076-2092.

${ }^{9}$ Traspuesta primero a través de la Ley $\mathrm{N}^{\circ} 23 / 2003$, de 10 de julio, de garantía en la venta de bienes de consumo; y después por el Texto refundido de la ley general de consumidores y usuarios, aprobado por el Real Decreto Legislativo $\mathrm{N}^{\circ} 1 / 2007$, de $16 \mathrm{de}$ noviembre.

${ }^{10}$ Véase: Morales Moreno, Antonio Manuel, Adaptación del Código Civil al derecho europeo: la compraventa (2003), ahora en La modernización del Derecho de obligaciones (Madrid, Thomson-Civitas, 2006), pp. 93-144. 
mercantil a partir de las instituciones, reglas y principios del nuevo derecho de contratos, además de regular de forma sistemática la prescripción y la caducidad. Fruto de este esfuerzo es el borrador elaborado por la Ponencia especial constituida en virtud de la Orden de 4 de marzo de 2003 y aprobado el 16 de marzo de 2004 tras cinco reuniones de trabajo. Dos años después, el 1 de febrero de 2006, se publicó la versión definitiva de la PACCom. ${ }^{11}$, que se corresponde exactamente con el borrador inicial.

Paralelamente, la Sección de Derecho Mercantil se embarcó en un ambicioso proyecto alternativo que, por su incompatibilidad, impide que la PACCom. pueda finalmente convertirse en ley. Este proyecto consiste en la elaboración de un Código Mercantil ${ }^{12}$, iniciativa que fue aprobada en la sesión de 28 de junio de 2005, y que viene a subsumir en su regulación las materias contenidas en ella. Tal cometido se formalizó a través de la Orden de 7 de noviembre de 2006, por la que el Ministerio de Justicia encargó a la Comisión General de Codificación "la elaboración de un nuevo Código Mercantil que sustituya al Código de Comercio de 1885, [...] en el que se integrará y delimitará la legislación mercantil existente y se modernizará y completará, en la medida que se estime oportuno, la regulación vigente que afecta a las relaciones jurídico-privadas vinculadas con la exigencias de la unidad de mercado"13. La mayor novedad que comporta esta tarea es que, para la sistematización del nuevo texto legal, se ha propuesto la utilización de "la numeración de los libros, capitulos y articulos características de la nueva codificación francesa".

La labor de más difícil emprendimiento que comporta la factura de un nuevo Código Mercantil es, sin duda alguna, la delimitación de aquella materia comprendida por el derecho mercantil. Si se parte de los criterios dados por la Orden ministerial, el criterio de diferenciación es ahora el concepto de mercado, cuya unidad explica la del derecho privado que lo regula y que, por esa misma razón, se atribuye constitucionalmente al Estado, con eficacia espacial en todo el territorio nacional (artículo 149.1.6 de la Constitución Española $)^{14}$. El nuevo Código de Comercio cumpliría, entonces,

${ }^{11}$ Publicado en Boletín de Información del Ministerio de Justicia, 60 (2006), pp. 605-618.

${ }^{12} \mathrm{El}$ nombre del futuro texto es también una cuestión sobre la que se debe tomar alguna decisión. Además de la ya clásica nomenclatura de "Código de Comercio" (empleado por el código francés de 1807 y por los dos que ha tenido España), se puede nominar el nuevo esfuerzo de fijación con el nombre de "Código Mercantil”, como lo hace la Orden ministerial de 7 de noviembre de 2006 y la propia Comisión General de Codificación en sus Memorias anuales, o bien con el de "Código empresarial", término este último que presenta una mayor coherencia dogmática (cfr. artículo 1 PACCom.).

${ }^{13}$ Apud Olivencia Ruiz, Un Código Mercantil, cit. (n. 1), p. 58.

${ }^{14}$ Ibíd., p. 61. 
una función de baluarte de ciertas instituciones que quedarían a cubierto del peligro de invasión de la competencia exclusiva del Estado en materia de legislación mercantil, frente a la creciente expansión de las legislaciones autonómicas, con el consiguiente resguardo de los principios de unidad de mercado y libertad de empresa ${ }^{15}$. Al mismo tiempo, este código ofrecerá a los empresarios y operadores jurídicos que desarrollan funciones en España un conjunto de reglas de derecho privado mercantil, no solamente ordenadas sistemáticamente (con la particular modalidad de la codificación a derecho constante), sino también fácilmente obtenibles y aplicables ${ }^{16}$.

Una vez fijado ese ámbito, los aspectos subjetivo y objetivo de esta parcela quedan igualmente determinados. Para el derecho mercantil, son sujetos relevantes todos aquellos que ejercen profesionalmente y en nombre propio una actividad económica en el mercado, sin importar que lo hagan como personas naturales o bajo una particular forma societaria (artículo 1.1 PACCom.). Así, la frontera queda establecida entre quienes intervienen en el mercado mediante el ejercicio habitual de una actividad económica, sin exclusión de una clase determinada de éstas, y quienes lo hacen por cuenta ajena, mediante un contrato de trabajo ${ }^{17} \mathrm{u}$ otra forma de prestación de servicios análoga ${ }^{18}$, o por cuenta propia y fuera del ámbito de dirección y organización de otra persona ${ }^{19}$.

De igual forma, son reputados sujetos de derecho mercantil aquellos que intervienen en el mercado como destinatarios finales de bienes y servicios enderezados a satisfacer una necesidad personal o familiar, esto es, ajena a cualquier actividad profesional o empresarial (artículo 1.2 PACCom.), y a quienes la Constitución española menciona especialmente como dignos de protección por parte de los poderes públicos (artículo 51). Por atracción, todo el derecho del consumidor debería pasar a integrar el proyectado Código Mercantil, sin que tal inclusión suponga una eliminación del orden público de protección ínsito a él. En la actualidad ya no parece posible concebir un derecho mercantil que atienda sólo a uno de los agentes del mercado, dado

${ }^{15}$ Illescas Ortiz, Un nuevo Código de Comercio, cit. (n. 1), p. 2; Vicent ChuLIÁ, Francisco, Las misiones del Derecho mercantil, en GómEZ SEgADE, José Antonio GARCía VIDAL, Ángel (editores), El Derecho mercantil en el umbral del siglo XXI. libro Homenaje al Prof. Dr. Carlos Fernández-Nóvoa en su octogésimo cumpleaños (Madrid, Marcial Pons Ediciones Jurídicas y Sociales, 2010), p. 102.

${ }^{16}$ Illescas Ortiz, Un nuevo Código de Comercio, cit. (n. 1), p. 1.

${ }^{17}$ Véanse los artículos 1.1 y 2 de la Ley del estatuto de los trabajadores.

${ }^{18}$ Como acaece, por ejemplo, con el contrato especial de trabajo del personal de alta dirección regulado por el Decreto $\mathrm{N}^{\circ} 1382 / 1985$, de 1 de agosto, o con aquellas relaciones que quedan excluidas del ámbito del derecho del trabajo merced del artículo 1.3 de la Ley del estatuto de los trabajadores.

${ }^{19}$ Véase la Ley $\mathrm{N}^{\circ} 20 / 2007$, de 11 de julio, Ley del estatuto de los trabajadores. 
que la economía contemporánea se halla construida en buena medida sobre el consumo y una parte importante de sus protagonistas son los consumidores $^{20}$.

Con este espectro amplio de sujetos, el acto de comercio puede seguir siendo definido de la forma amplia y funcional en que lo hace hoy el artículo 2.2 del Código de Comercio: "Se reputarán actos de comercio los comprendidos en este Código y cualesquiera otros de naturaleza análoga"; norma que, al menos en la PACCom., no sufre modificación alguna.

Asimismo, el nuevo Código Mercantil operará una refundición y reordenación de aquellas materias reguladas por leyes especiales que han sustituido partes del Código de Comercio, reafirmando de ese modo su carácter mercantil $^{21}$. En este sentido, el código quiere revestir el carácter de un texto de recopilación, sistematización, coherencia y simplificación de la legislación actual y de la que en el futuro se produzca en el ámbito mercantil ${ }^{22}$. El objetivo primordial de esta operación codificadora debería comportar, pues, una mejora de la técnica legislativa empleada hasta ahora en esta parcela, que permita colmar las lagunas actualmente existentes (por ejemplo, la ausencia de regulación del arrendamiento financiero), establecer las coherencias que fueren necesarias (verbigracia, la armonía que exige el complejo y siempre oscuro entramado de los contratos de agencia, distribución y otros más o menos similares) y proceder a las actualizaciones imprescindibles respecto de determinadas materias (como la gratuidad que por defecto establece el artículo 314 CCom. para el préstamo de dinero $)^{23}$.

Fuera del Código Mercantil quedarían, empero, dos sectores que tradicionalmente han formado parte integrante de la regulación comercial, pero que hoy gozan de una autonomía dogmática fundada en los sendos textos legislativos existentes o proyectados para ellas. Tal es el caso del derecho concursal (libro IV de los Códigos de Comercio de 1829 y de 1885) y el derecho marítimo (libro III CCom.) ${ }^{24}$. El primero de ellos debería quedar regulado de forma única mediante una versión reformada de la Ley Concursal (Ley $\mathrm{N}^{\circ}$ $22 / 2003$, de 9 de julio ${ }^{25}$, mientras que el segundo habría de estar contenido

\footnotetext{
${ }^{20}$ Illescas Ortiz, Un nuevo Código de Comercio, cit. (n. 1), pp. 2-3.

${ }^{21}$ Ibíd., p. 2; Vicent Chuliá, Las misiones del derecho mercantil, cit. (n. 15), p. 102.

${ }^{22}$ Ibíd., p. 2.

${ }^{23}$ Ibíd., pp. 2-3.

${ }^{24}$ Ibíd., p. 3; Vicent Chuliá, Las misiones del derecho mercantil, cit. (n. 15), p. 102.

${ }^{25}$ Mediante Orden de 9 de julio de 2009, se constituyó en el seno de la Comisión General de Codificación una Sección Especial para la reforma de la Ley concursal operada por el Real Decreto-ley $N^{\circ} 3 / 2009$, de 27 de marzo, de medidas urgentes en materia tributaria, financiera y concursal ante la evolución de la situación económica, con el propósito de que ésta elabore una propuesta de anteproyecto de ley sobre la referida materia, que habrá de constar de memoria explicativa, exposición de motivos y texto
} 
en la Ley de navegación marítima que se discutía en el Parlamento ${ }^{26}$, cuyas instituciones, reglas y principios podrían ser aplicados, mutatis mutandis, en una posible Ley de transporte aéreo de mercancías sobre la que se ha comenzado a trabajar en el seno de la Comisión General de Codificación.

Cuestión de más difícil solución es el destino que ha de tener el derecho societario. Merced de la Orden ministerial de 28 de octubre de 2005, existe una Ponencia que se encuentra abocada al estudio de un futuro Código de Sociedades Mercantiles, cuyo sustrato es la frustrada Propuesta de igual nombre aprobada el 16 de mayo de 2002 y publicada el 2 de noviembre de ese año ${ }^{27}$. Este Código constituiría la etapa de culminación del proceso de reforma y armonización del derecho societario español, en el que hasta el momento se han dictado dos importantes leyes, a saber: la Ley $\mathrm{N}^{\circ} 3 / 2009$, de 3 de abril, sobre modificaciones estructurales de las sociedad mercantiles; y el Real Decreto Legislativo $N^{\circ} 1 / 2010$, de 2 de julio, por el que se aprueba el texto refundido de la Ley de sociedades de capital. Cabe destacar que la "Exposición de Motivos" de este último deja abierta la posibilidad de que el derecho societario quede contenido o bien en un código propio, o bien en el proyectado Código Mercantil. Llegado el momento, los textos preparados

articulado, a los que se acompañarán los documentos complementarios que la Sección Especial estime oportunos.

${ }^{26}$ El 11 de diciembre de 2008, la Asamblea General de las Naciones Unidas adoptó el Convenio sobre el contrato de transporte internacional de mercancias total oparcialmente marítimo (llamado Reglas de Rotterdam), por el que se establece un régimen legal, uniforme y moderno a través del cual se regulan los derechos y obligaciones de los cargadores, porteadores y destinatarios sujetos a un contrato de transporte de puerta a puerta que comprenda algún tramo internacional por vía marítima. Al respecto, véanse: ILLESCAS OrTIZ, Rafael, Lo que cambia en el derecho del transporte internacional tras las Reglas de Rotterdam, en Gómez Segade, José Antonio - García Vidal, Ángel (editores), El Derecho mercantil en el umbral del siglo XXI. libro Homenaje al Prof. Dr. Carlos Fernández-Nóvoa en su octogésimo cumpleaños (Madrid, Marcial Pons, 2010), pp. 591-599. Tan sólo dos días antes, el 9 de diciembre, el Gobierno había presentado en el Congreso de los Diputados el de una Ley de navegación maritima (Proyecto $\mathrm{N}^{\circ} 121 / 000014$ ), que no fue aprobado y finalmente caducó el 27 de septiembre de 2011.

${ }^{27}$ Sobre ella, véanse: DE la CÁmara Álvarez, Manuel, Comentarios al Anteproyecto o Propuesta de Código de Sociedades Mercantiles, en Delgado de Miguel, Juan Francisco (coordinador), Instituciones de Derecho privado, VI, 2: Derecho de sociedades. Parte especial (Madrid, Editorial Civitas, 2004), pp. 19-171 = Delgado DE Miguel, Juan Francisco (coordinador), Instituciones de Derecho privado, VI-5: Derecho mercantil especial (Madrid, Editorial Civitas, 2005), pp. 17-194; EmbID Irujo, José Miguel, La regulación de los grupos en la Propuesta de Código de Sociedades Mercantiles, en VV. AA., Estudios de Derecho de sociedades y Derecho concursal. libro homenaje al profesor Rafael Garcia Villaverde (Madrid, Marcial Pons, 2007), I, pp. 389-408; TAPIA Hermida, Alberto Javier, Propuesta de Código de Sociedades Mercantiles, en Revista de Derecho Bancario y Bursátil, 89 (2003), pp. 413-414. 
por la mentada Comisión "habrán de ser valorados por el Gobierno a fin de decidir el tiempo y el modo de tan ambiciosa reforma" ("Exposición de Motivos", V) ${ }^{28}$.

El último aspecto a destacar en la redacción del nuevo Código Mercantil es la forma de numeración que se ha elegido para su articulado. La modalidad propuesta se compone de tres cifras para identificar, respectivamente, el libro, título y capítulo al que el artículo pertenece; dentro de cada capítulo, por su parte, se numerarán los artículos en orden correlativo a partir del 1. Con este sistema, al ser independiente la individualización de cada capítulo, no se alterará la del articulado si se introduce un capítulo nuevo, ni quedarán artículos sin contenido cuando algunos de ellos se derogaren. De esta forma, se favorece la integración y ordenación de las normas existentes, su modificación o adición sin que padezca la correlativa numeración del código y, en consecuencia, la coherencia interna del sistema ${ }^{29}$. Durante 2007, la Sección Mercantil aprobó el texto correspondiente al libro V del nuevo Código Mercantil, que estará dedicado a las obligaciones y contratos mercantiles en general y en el que se subsume, por consiguiente, la PACCom.

\section{LA “PROPUESTA” Y SU INCIDENCIAEN LA CONFIGURACIÓN DEL DERECHO MERCANTIL ESPAÑOL}

La PACCom. pretende dar una nueva redacción a los artículos 1 y 50-63 CCom., además de utilizar el sitio dejado por sus derogados artículos $64-80^{30}$, con normas enderezadas a crear una disciplina general de los contratos mercantiles más elaborada que la actualmente existente ${ }^{31}$. También se propone

${ }^{28}$ Vicent Chuliá, Las misiones del derecho mercantil, cit. (n. 15), p. 102, por ejemplo, es partidario de que el derecho societario quede regulado al margen del Código Mercantil.

${ }^{29}$ Illescas Ortiz, Un nuevo Código de Comercio, cit. (n. 1), p. 3.

${ }^{30}$ Estos artículos trataban sobre los lugares y casas de contratación mercantil, y fueron derogados en su día por la Ley de mercado de valores (Ley $\mathrm{N}^{\circ} 24 / 1988$, de 28 de julio).

${ }^{31}$ Propiamente, la numeración de los artículos que aquí se ofrece corresponde a aquellos que la PACCom. desea introducir en el Código de Comercio. No se trata, por consiguiente, de normas que estén numeradas de esa forma en la citada Propuesta, que sólo está integrada por tres artículos: el primer dedicado a modificar el artículo 1 del Código de Comercio; el segundo enderezado a dotar de contenido el nuevo título IV que se desea introducir en su libro I; y el tercero referido a los nuevos títulos II y III de su libro IV. Sin embargo, para evitar confusiones entre los actuales artículos del Código de Comercio y aquellos que la PACCom. contiene, se ha preferido designar estos últimos con la indicación de su pertenencia a tal Propuesta. El mismo criterio se utilizará respecto de la PMCC. 
modificar los artículos 942-955, que con la nueva redacción se reparten entre los referidos a la regulación de la prescripción (artículos 942-950) y aquellos que tratan sobre la caducidad (artículos 953-955).

Como primer rasgo característico, la PACCom. contiene diversas normas cuyo supuesto de hecho está definido, exclusiva o preferentemente, a partir de los contratos de larga duración o de red, por lo que se halla estrechamente relacionado con otra Propuesta elaborada conjuntamente y referida a los contratos de distribución ${ }^{32}$. Con esta última se deseaba colmar la carencia existente en el ordenamiento español de una normativa reguladora de los distintos tipos de contratos vinculados al fenómeno de la distribución comercial, de suerte que merced a esta nueva disciplina aumentase la seguridad jurídica en la materia y se evitase la aparición de situaciones de abuso cuando no existe equilibrio entre los contratantes (Memoria explicativa, I), sin menoscabar con ello la libre interacción de los principios de libertad de empresa y autonomía de la voluntad (Memoria explicativa, II). Para construir el régimen de esta clase de contratos se tomaron como referencia, entre otras fuentes, los Principios UNIDROIT sobre contratos comerciales internacionales (PICC) y los trabajos preparatorios de este instituto sobre una "Ley modelo de contrato de franquicia" (Memoria explicativa, I).

Un segundo aspecto interesante de la PACCom. es que su diseño responde a uno de los objetivos que persigue el actual momento codificador. Para éste, lo importante es la creación de una legislación sistemática y simplificada en diversos niveles de regulación y racionalización normativa, cada uno de ellos dotado de una mayor inmutabilidad y perdurabilidad que el anterior, sin desconocer la realidad del fenómeno jurídico sobre el que esas normas influyen ${ }^{33}$. En este sentido, la Propuesta se hace cargo del carácter fragmentario, incompleto y obsoleto que se observa en vastos sectores del derecho mercantil, particularmente en el Código de Comercio, y reconoce que es imprescindible una modernización de esa legislación en el ámbito de los contratos mercantiles ("Preámbulo", $\$ 1$ y 3 ). Como presupuesto lógico y dogmático, dicha reforma debe comenzar por establecer los principios generales aplicables a esta clase de contratos y por regular dos instituciones fundamentales para asegurar la seguridad del tráfico jurídico, como son la prescripción y la caducidad ("Preámbulo", \$\$ 2 y 3 ). A partir de esas bases, la PACCom. ofrece una regulación completa y detallada de los contratos mercantiles, que queda conformada de forma autónoma a la existente en

\footnotetext{
${ }^{32}$ Publicada en Boletín de Información del Ministerio de Justicia, 60 (2006), pp. 618629 = Revista de Derecho de la Competencia y la Distribución, 2 (2008), pp. 287-298.

${ }^{33}$ Menéndez Menéndez, Aurelio, Notas a propósito de la codificación mercantil, en Llamas Pombo, Eugenio (coordinador), Estudios de Derecho de obligaciones en homenaje al Profesor Mariano Alonso Pérez (Madrid, Editorial La Ley, 2006), II, p. 393.
} 
el Código Civil, al que ya no será necesario remitirse para dar solución a un gran número de cuestiones. Dicha regulación contiene, además, las normas básicas en la materia expuestas en un lenguaje fácilmente comprensible, no sólo para los operadores jurídicos, sino también para todos sus destinatarios (Preámbulo, $\$ 6$ ).

Otro aspecto relevante es la introducción de normas dirigidas a otorgar seguridad jurídica a los agentes del mercado, muchas de ellas a través de la positivización de principios y reglas de decantada elaboración doctrinal y jurisprudencial. Es lo que sucede, por ejemplo, con el establecimiento de un nuevo régimen para la prescripción y la caducidad, y con la consagración de los deberes precontractuales, el principio de interdicción de los actos propios, la excesiva onerosidad sobreviniente y el nuevo diseño del sistema de remedios ante el incumplimiento contractual.

Asimismo, la adaptación de las normas mercantiles a los textos del nuevo derecho de contratos que opera la PACCom. permite avanzar en la necesaria modernización del derecho español, senda que ha seguido también la PMCC. ("Exposición de Motivos", III y IV). Con todo, quizá una de las mayores innovaciones metodológicas de la Propuesta en comento sea la decisión de considerar el derecho del consumo como parte integrante del derecho mercantil, evitando las tendencias centrífugas que buscan situarlo dentro del derecho civil o convertirlo en una rama equidistante de ambos ${ }^{34}$. Como fuere, el problema de calificación de esta parcela es más bien teórico, ya que la existencia de una normativa especial reguladora de los contratos de consumo priva en gran medida de relevancia a la cuestión de su adscripción a una determinada rama dogmática: tal disciplina se aplica a todos los contratos de consumo, creando a su respecto un orden público de protección, con independencia de su naturaleza civil o mercantil ${ }^{35}$.

Hecho ya el acercamiento conceptual a la PACCom., queda referir su estructura, dividida en tres partes. La primera se dirige a reemplazar el artículo 1 CCom., para sustituir en él el concepto de comerciante por el de empresario e introducir una mención a los consumidores como sujetos del derecho mercantil. La segunda parte busca dotar de una nueva sistemática al

${ }^{34}$ Véase: Pinochet Olave, Ruperto, ¿Integra el Derecho de consumo el Derecho civil, el Derecho mercantil o conforma una disciplina jurídica autónoma? en GUZMÁN BRITO, Alejandro (editor), Estudios de Derecho civil III (Santiago, LegalPublishing, 2008), pp. 9-20.

${ }^{35}$ Miranda Serrano, Luis María, La contratación mercantil en general: su actual fisonomia y otras cuestiones preliminares, en Olivencia, Manuel - FernándeZ-NóvoA, Carlos - Jiménez De PARGa, Rafael (directores), Tratado de derecho mercantil, XXX: La contratación mercantil. Disposiciones generales. Protección de los consumidores (Madrid, Marcial Pons Ediciones Jurídicas y Sociales, 2006), p. 39. 
título $4^{\circ}$ del libro I, que queda dispuesta de la siguiente forma: en la sección primera se trata del régimen jurídico general de los contratos mercantiles; en la segunda de los deberes precontractuales; en la tercera de la perfección del contrato; en la cuarta de su interpretación; en la quinta de su contenido; en la sexta del cumplimiento; en la séptima de la extinción y excesiva onerosidad; en la octava del incumplimiento; en la novena de la morosidad en el cumplimiento; en la décima de la cesión de créditos mercantiles; y en la undécima de la solidaridad en las obligaciones mercantiles. Por último, la PACCom. reemplaza los títulos $2^{\circ}$ y $3^{\circ}$ del libro IV, que ahora quedan destinados a disciplinar, respectivamente, la prescripción y la caducidad.

\section{UNA NUEVA MATRIZ DISCIPLINAR PARA EL DERECHO MERCANTIL}

Para el Código de Comercio, el derecho mercantil es un conjunto sistemático de normas y principios especiales, distinto del derecho civil o común, cuyo contenido viene delimitado por sus artículos 1 y 2 en torno a dos nociones: i) la de comerciante, que comprende al empresario individual y las sociedades mercantiles (artículos 3, 4, 16, 116, 119 y 122); y ii) la de acto de comercio, definido de forma comprensiva, práctica y flexible ("Exposición de Motivos", $\$ 15$ ), siguiendo un procedimiento de referencia y analogía, como todo aquel que se halle comprendido en el Código de Comercio y cualesquiera otro de naturaleza similar, sin referencia a una catálogo exhaustivo como acaecía en el Code de Commerce francés de 1807 (artículos 631, 632 y 633, hoy reformulados en los artículos L110-1 y L110-2 del código de 2000) ${ }^{36}$.

La innovación introducida por la PACCom. consiste en desplazar el centro de gravedad de esta disciplina desde el comerciante al empresario, concepto éste que sustituye a aquél en todo el sistema del código (artículo 1.3). Según su Preámbulo, este reemplazo se explica porque una de las consecuencias que se desprende del principio de unidad de mercado es que se haya de asegurar que las normas aplicables en la contratación de los empresarios rijan para todos los contratos que realicen dentro del territorio español, sin importar la calidad de aquel con el que contratan $(\$ 8)$. Se hace explícita, por tanto, la idea ya presente en el texto originario del código de 1885, que

\footnotetext{
${ }^{36}$ Miranda Serrano, La contratación mercantil, cit. (n. 35), pp. 28 y 32-34; VICent Chuliá, Francisco, Introducción al Derecho mercantil (21 a edición, Valencia, Tirant Lo Blanch, 2008), p. 42. Más adelante, este último autor explica que la noción de acto de comercio es comprensiva tanto de actos (la entrega de mercaderías, el pago del precio, el abordaje, y las declaraciones, registros y estados contables) como de negocios jurídicos (principalmente, los contratos mercantiles) [p. 888].
} 
ordenaba la actividad comercial a partir del concepto de comerciante y, por extensión, del de empresario (artículos 1 y 116).

Los conceptos de empresario y consumidor están actualmente definidos en la Ley general de defensa de los consumidores y usuarios (Real Decreto Legislativo $\mathrm{N}^{\circ} 1 / 2007$, de 16 de noviembre). De acuerdo con esta ley, “[...] se considera empresario a toda persona física o jurídica que actúa en el marco de su actividad empresarial o profesional, ya sea pública o privada" (artículo 4); y “[...] consumidores o usuarios [a] las personas físicas o jurídicas que actúan en un ámbito ajeno a una actividad empresarial o profesional” (artículo 3). La PACCom. se aparta de estas definiciones, en especial en lo que se refiere a la categoría de consumidor. Conforme a ella, son empresarios todas las personas naturales o jurídicas que ejercen profesionalmente y en nombre propio una actividad económica en el mercado, y en todo caso las sociedades que adopten alguno de los tipos mercantiles (artículo 1.1). Se aprecia en este nuevo concepto no sólo una modernización del vocablo empleado en el pórtico del Código de Comercio, que ya es de agradecer, sino también una ampliación de la matriz disciplinar del derecho mercantil, para incluir dentro de su ámbito cualquier actividad económica, sin reducir su supuesto a las consideradas tradicionalmente comerciales (las de intercambio) ${ }^{37}$. Con esto, toda actividad que implique una prestación de servicios queda clara y expresamente amparada en la definición ${ }^{38}$, permitiendo una mejor comprensión del núcleo dogmático del derecho mercantil, caracterizado por la institucionalización de la empresa, del establecimiento y de la actividad empresarial en sus cuatro aspectos ordenadores, a saber: organización, colaboración, intercambio y competencia ${ }^{39}$.

Por lo que respecta al concepto de consumidor, en la PACCom. únicamente se reputan tales "las personas naturales que realicen contratos con una finalidad ajena a cualquier actividad profesional o empresarial" (artículo 1.2), para adecuar así su definición a las directivas comunitarias y al criterio recogido en la jurisprudencia del Tribunal de Justicia de las Comunidades Europeas ${ }^{40}$, según los cuales aquél es necesariamente una persona natural

${ }^{37}$ Bercovitz Álvarez, Propuesta de Anteproyecto, cit. (n. 1), p. 305.

${ }^{38}$ Los Principles of European Law on Service Contracts (PELSC, 2007) definen el contrato de prestación de servicios de forma amplia, como aquel en el que una parte (el proveedor) debe prestar a la otra (el cliente) un servicio a cambio de una remuneración [artículo 1:101 (1)].

${ }^{39}$ Vicent Chuliá, Introducción, cit. (n. 36), p. 74.

${ }^{40}$ En este sentido, Tribunal de Justicia de las Comunidades Europeas (Sala Tercera), sentencia de 22 de noviembre de 2001, caso Cape Snc y otros contra Idealservice Srl y otros (asuntos acumulados C-541/99 y C-542/99), rol TJCE $2001 / 330$. 
(Preámbulo, §9). Con todo, esta alteración no tendrá mayor incidencia en el posterior desarrollo jurisprudencial, porque desde hace algún tiempo la Ley general de defensa de los consumidores y usuarios viene siendo interpretada en el mismo sentido. De hecho, se ha entendido que las sociedades mercantiles no pueden ser reputadas destinatarias finales de los productos que adquieren y de los servicios que contratan, pues éstos siempre quedan integrados de alguna forma en su proceso productivo ${ }^{41}$. El cambio legislativo que opera la PACCom. afectará, en consecuencia, solamente a aquellas instituciones que carecen de ánimo de lucro (asociaciones, fundaciones, ONG) y que, en algunos casos, pueden ser consideradas destinatarios finales de bienes y servicios ${ }^{42}$. El objetivo de esta definición de nuevo cuño es evitar la invocación de la noción de consumidor por parte de esta clase de entidades, que realmente no necesitan contar con una posición reforzada para actuar en el tráfico comercial.

Sin embargo, una hipotética aprobación de la PACCom. debería ir aparejada de una modificación del artículo 1.2 de la Ley general de defensa de los consumidores y usuarios, ya que en caso contrario existirá entre ambas disposiciones un conflicto normativo, introduciéndose inseguridades ahí donde antes no las había. Una cuestión diferente es que el legislador utilice una noción de consumidor distinta para la regulación de determinados sectores específicos respecto de los cuales se haya querido establecer un espectro de protección más amplio ${ }^{43}$. Así sucede, verbigracia, en la Ley $\mathrm{N}^{\circ} 21 / 1995$, de 6 de julio, reguladora de viajes combinados, ahora refundida como libro IV de la Ley general de defensa de los consumidores y usuarios, que define al consumidor o usuario como "[c] ualquier persona en la que concurra la condición de contratante principal, beneficiario o cesionario" [artículo 151.1 g) de la última ley citada], sin limitación a su carácter de persona natural.

\section{EL RÉGIMEN JURÍDICO DE LOS CONTRATOS MERCANTILES}

El régimen jurídico de los contratos mercantiles se halla recogido en el artículo 50 PACCom., donde se hace referencia a su ámbito de aplicación (1), la vigencia de la libertad contractual en esta parcela del derecho (2), el carácter consensual de esta clase de contratos (3) y la eficacia de la contratación electrónica (4).

${ }^{41}$ Bercovitz Álvarez, Propuesta de Anteproyecto, cit. (n. 1), p. 305.

${ }^{42} \mathrm{Al}$ respecto, véase: ЕмвіD IRUjo, José Miguel, Notas sobre el régimen jurídico de las entidades sin ánimo de lucro, su estructura interna y la responsabilidad de los órganos gestores (especial referencia a las fundaciones), en Revista Valenciana de Economia y Hacienda, 7 (2003), pp. 84-87.

${ }^{43}$ Bercovitz Álvarez, Propuesta de Anteproyecto, cit. (n. 1), p. 306. 


\section{El ámbito de aplicación del derecho de la contratación mercantil.}

En la PACCom., un contrato es considerado mercantil en atención de la persona que lo celebra (artículo 50) ${ }^{44}$. Según aquélla, revisten tal carácter los contratos celebrados por empresarios en el ejercicio de su actividad profesional, incluidos los realizados con consumidores. Son, pues, el concepto de empresa y el ámbito de acción de ésta los que permiten calificar de esta forma un determinado contrato (artículo 50.1 PACCom.), modificando el criterio objetivo establecido en el artículo 2 CCom., cuyo texto no queda, empero, derogado. Ésta es una de las innovaciones de mayor calado de la mentada Propuesta, pues con ella se establece que los contratos celebrados por los consumidores en su condición de tales son siempre mercantiles y, por consiguiente, se encuentran sujetos a las reglas del Código de Comercio y la regulación mercantil especial ${ }^{45}$.

Otro aspecto relevante es la prelación normativa que viene a establecer el artículo 50.2 PACCom.. En ella se hace referencia a los usos mercantiles en el mismo lugar en que los sitúa el artículo 2 CCom., eliminando así cualquier duda sobre la supuesta especialidad en la que éstos se encuentran a tenor del actual artículo 50, que remite directamente a las reglas generales de derecho común en todo lo que no se halle expresamente previsto en aquel código o en leyes especiales. El orden de prelación ofrecido en la PACCom. supone recurrir, ante todo, a las disposiciones del Código de Comercio y las leyes que lo complementan; en su defecto a los usos mercantiles observados en el sector económico de que se trate, y a falta de éstos a las disposiciones de derecho común.

En fin, habría sido de agradecer que, pese a tratarse de una disciplina propia de los contratos, en la PACCom. se hubiese hecho alguna alusión a los negocios jurídicos unilaterales que inciden en el derecho mercantil, especialmente en lo que atañe a la promesa pública de recompensa (Auslobung) y los negocios subjetivamente complejos ${ }^{46}$.

\section{La libertad contractual.}

La libertad contractual es un principio aceptado desde antiguo en la

${ }^{44}$ Sobre esta calificación en el Código de Comercio, véase: Miranda Serrano, $\mathrm{La}$ contratación mercantil, cit. (n. 35), pp. 32-36; VICENT CHULIÁ, Introducción, cit. (n. 36), pp. 887-892.

${ }^{45}$ Bercovitz Álvarez, Propuesta de Anteproyecto", cit. (n. 1), p. 304.

${ }^{46}$ Véase Miranda Serrano, Luis María, Las disposiciones del Código de Comercio sobre el contrato y la obligación mercantil en general', en Olivencia, Manuel - Fernández-Nóvoa, Carlos - Jiménez de PARGa, Rafael (directores), Tratado de Derecho mercantil, XXX: La contratación mercantil. Disposiciones generales. Protección de los consumidores (Madrid, Marcial Pons, 2006), pp. 154-156. 
doctrina y en el derecho comparado (verbigracia, artículos 1255 CCEsp. y 1322 del Codice Civile italiano). La PACCom. hace lo propio y reconoce que los contratantes tienen libertad para celebrar cualquier clase de contratos mercantiles, aunque no se encuentren tipificados en la ley (artículo 50.3); y que pueden establecer en ellos las estipulaciones que tengan por convenientes, siempre que no sean contrarias a la ley, la moral o el orden público (artículo 50.4)

\section{El carácter consensual de los contratos mercantiles.}

En la PACCom., la perfección, modificación y extinción de los contratos mercantiles, salvo disposición en contrario, se produce por el mero consentimiento de las partes (artículo 50.5), de la misma forma que acaece bajo el actual artículo 51 CCom. ("Exposición de Motivos", $\$ 53$ y 54$)^{48}$. Se exceptúan los casos en que la ley ha dispuesto que un determinado contrato se sujete a ciertas formalidades ${ }^{49} \mathrm{y}$ aquellos en que las partes han establecido que cualquier modificación o extinción del contrato se realice por escrito (artículos 50.4 y 50.6 PACCom. ${ }^{50}$. De esta forma, la PACCom. busca otorgar a los contratantes un mecanismo que les permita, a menos que ellas mismas estipulen lo contrario, modificar sus contratos en curso sin mayores formalidades y, consecuencialmente, con un menor compromiso de recursos económicos.

La modificación convencional del contrato encuentra un límite, con todo, en el comportamiento que las partes hubieran demostrado durante su ejecución, esto es, en el principio de interdicción de los actos propios. Si el comportamiento de una de ellas respecto de la cláusula de modificación o extinción del contrato hubiera generado en la otra una confianza legítima sobre el mantenimiento en el tiempo de ese estado de cosas, la posterior invocación de dicha cláusula debe ser necesariamente rechazada (artículo 50.6 PACCom.).

Nada dice la PACCom. sobre la prueba de los contratos mercantiles. En ella no existe siquiera una norma como el actual artículo 51 CCom., conforme al cual se puede demostrar la existencia de un contrato mercantil con tal de que ésta conste "por alguno de los medios que el Derecho civil tenga establecidos”, y siempre que no se esté ante unos de los supuestos excepcionales contenidos en el propio código (artículos 51 y 52). Este reenvío se ha de

${ }^{47}$ Véase el artículo 1237.1 PMCC.

${ }^{48}$ Véase el artículo 1239 PMCC.

${ }^{49}$ Una referencia a estos casos, al tenor de la legislación actualmente en vigor, en Miranda Serrano, Las disposiciones del Código de Comercio", cit. (n. 46), pp. 117123.

${ }^{50}$ Véase el artículo 1241 PMCC. 
entender efectuado hoy a la disciplina probatoria de la Ley de Enjuiciamiento $\mathrm{Civil}^{51}$, que contiene una mención expresa a los libros de los comerciantes dentro la sección dedicada a los documentos privados (artículo 327) y donde remite al valor que a éstos dé el Código de Comercio (artículos 25-33) ${ }^{52}$.

\section{La eficacia de la contratación electrónica.}

El artículo 50.8 PACCom. señala que los contratos electrónicos producirán los efectos previstos en el ordenamiento jurídico cuando concurran el consentimiento (cfr. artículo 52.2 PACCom.) y los demás requisitos necesarios para su validez, sin que se precise un acuerdo previo de las partes favorable a la utilización de medios electrónicos. A la vez, se considera suficiente para satisfacer la exigencia legal de que un contrato o cualquier otra información conste por escrito el que aquél o ésta se contenga en un soporte electrónico. La PACCom. repite, así, las reglas mencionadas en el artículo 23 de la Ley $\mathrm{N}^{\circ} 34 / 2002$, de 11 de julio, sobre servicios de la sociedad de la información y de comercio electrónico ${ }^{53}$, que excluye de su ámbito de aplicación sólo los contratos de familia y sucesorios. La prueba de esta clase de contratos queda regida por las reglas de los artículos 24 y 25 de la citada Ley $N^{\circ} 34 / 2002$ y 3 de la Ley 59/2003, de 19 de diciembre, de firma electrónica.

\section{LOS DEBERES PRECONTRACTUALES}

La PACCom. contiene una detallada regulación de los deberes precontractuales, que hasta ahora no se encontraban tipificados en el derecho español, pese a que la doctrina y la jurisprudencia los entendían incorporados en

${ }^{51}$ Martín Rodríguez, María Ángeles, La unificación civil y mercantil en la contratación privada (Madrid, Editorial Universitaria Ramón Areces, 2006), pp. 146 y 233; Miranda Serrano, Las disposiciones del Código de Comercio, cit. (n. 46), p. 125.

${ }^{52}$ Como advierte Miranda Serrano, Las disposiciones del Código de Comercio, cit. (n. 46), p. 132, el Tribunal Supremo español ha restringido bastante el alcance del valor probatorio de la contabilidad: su jurisprudencia afirma que los libros de los comerciantes no constituyen un medio de prueba privilegiado y que la contabilidad sólo acredita hechos y no negocios jurídicos, toda vez que los contratos no son objeto de anotación contable. La contabilidad sí permite demostrar, en cambio, el contenido de las prestaciones que realizan las partes en ejecución de un contrato, carácter que le otorga una especial idoneidad para dar por establecidos ciertos hechos de los que derivan efectos jurídicos.

${ }^{53}$ Esta ley comporta la trasposición de la Directiva N ${ }^{\circ} 2000 / 31 / C E$ del Parlamento Europeo y del Consejo, de 8 de junio de 2000, relativa a determinados aspectos jurídicos de los servicios de la sociedad de la información, en particular el comercio electrónico en el mercado interior. 
el itinerario contractual merced el efecto normativo del principio de buena fe (artículos 7.1 y 1258 CCEsp. y 57 CCom.). Estos deberes se reducen principalmente a dos: i) las negociaciones para celebrar un contrato deben ser llevadas a cabo de buena fe y con lealtad (artículo 51.1 PACCom.); y ii) cada una de las partes ha de mantener confidencialidad sobre la información que recibe de la otra durante el curso de esas negociaciones (artículo 51.4 PACCom.). Ambos deberes adquieren especial fuerza en las relaciones de red y de larga duración, paradigmas de la actual contratación, pues en ellas el carácter peculiar de la relación contractual exige un diseño negocial más exhaustivo, que necesariamente ha de considerar una serie de variables relacionadas con el objeto sobre el que se contratará, con las condiciones en que las prestaciones serán cumplidas y con la comparecencia de partes sofisticadas $^{54}$.

Consecuente con estos deberes, la PACCom. regula la responsabilidad derivada de la ruptura de las tratativas preliminares de un contrato. En principio, ambas partes son libres de retirarse de dichas negociaciones y, por ende, ninguna de ellas incurre en responsabilidad por el solo hecho de que no se consiga el acuerdo definitivo (artículo 51.2 PACCom.). Sólo existirá responsabilidad para esa parte cuando se haya negociado o interrumpido las negociaciones de mala fe (artículo 51.3 PACCom.) y, evidentemente, cuando el retiro de las tratativas pueda originar responsabilidad de acuerdo con el artículo 1902 CC.

Se echa en falta, empero, alguna referencia a los deberes de información y de custodia y conservación, que no necesariamente pueden ser deducidos de la regla general de negociar de buena fe y con lealtad establecida en el artículo 51.1 PACCom. Según el primero de ellos, cada parte debe entregar oportuna y precisamente las informaciones relacionadas con el contrato proyectado, notificando a la otra de la ocurrencia de cualquier circunstancia que rodee la negociación y pueda incidir en su conclusión. El único límite viene dado por el deber correlativo de confidencialidad sobre los acuerdos y la información ajena recibida, conforme al grado de cuidado con que cada parte protegería su propia información (artículo 51.4 PACCom.). A su vez, es muy probable que determinados bienes de las partes negociadoras resulten expuestos a riesgos y peligros que de otro modo no existirían, dado que aquéllos deben ser examinados o probados por éstas durante el curso de las tratativas. Para garantizar la posición de cada una de las partes, y siempre que la otra haya expresado su deseo en ese sentido, existe el deber de guardar

${ }^{54}$ Véase el artículo 1245 PMCC. 
y custodiar los bienes involucrados en la fase precontractual $^{55}$, del que la PACCom. nada dice.

\section{LA PERFECCIÓN DEL CONTRATO MERCANTIL}

En la sección tercera, la PACCom. se ocupa de disciplinar exhaustivamente la perfección del contrato mercantil, aunque su regulación no es tan extensa como la que dedica a esta cuestión la $\mathrm{PMCC}^{56}$. En esta parte, pese a existir coincidencia sustancial con los artículos 54 y 55 CCom., se observan algunas innovaciones referidas a algunos supuestos actualmente no comprendidos en la redacción vigente, como los de ofertas verbales (artículo 53.1 PACCom.), aceptación por actos concluyentes (artículos 52.2 y 54.1 PACCom.), plazo hábil para la aceptación (artículo 54.4 PACCom.), aceptación tardía (artículo 54.6 PACCom.), revocación de la oferta (artículo 53.3-53.6 PACCom.), delimitación de cuándo se está en presencia de una aceptación y cuándo ante una contraoferta (artículo 54.7 PACCom.), diferencia entre oferta e invitación a ofertar (artículo 53.2 PACCom.), etcétera ${ }^{57}$.

Particularmente, son dignas de destacar tres reglas relacionadas con la formación del contrato mercantil.

a) La primera de ellas está dirigida a facilitar la perfección de un contrato de esta clase, pues éste se reputa existir, a diferencia de lo que ocurre en el derecho común, desde que se ha aceptado la Propuesta (artículo 52.1 PACCom.)

${ }^{55}$ Barrientos Zamorano, Marcelo, Daños y deberes en las tratativas preliminares de un contrato (Santiago, LegalPublishing, 2008), p. 105.

${ }^{56}$ Esta Propuesta trata esta materia con referencia a los siguientes aspectos: $i$ ) el régimen general de formación del contrato por oferta y aceptación (artículos 1246-1259); ii) otros procedimientos de formación del contrato, como acaece con las subastas y los concursos (artículo 1260); iii) las condiciones generales de contratación (artículos 1261-1264); iv) los contratos celebrados fuera de los establecimientos mercantiles (artículos 1265 y 1266); v) la protección de los consumidores en los contratos a distancia (artículo 1267); y vi) la contratación electrónica (artículo 1268).

${ }^{57}$ En este ámbito existen algunas diferencias entre la PACCom. y la PMCC., en especial en lo que atañe al lugar en que se entiende celebrado el contrato cuando el oferente y el aceptante se hallan en lugares distintos. Para la primera, la aceptación surte sus efectos en el momento en que llega al oferente (artículo 54.2); de donde cabe entender que el contrato se entiende celebrado en el lugar en el que éste tenga su domicilio. La PMCC., por el contrario, ofrece la regla inversa y ya existente en los artículos 1262 CCEsp. y 54 CComEsp. después de la redacción unificada que les fue dada por la disposición adicional $4^{\text {a }}$ de la Ley $\mathrm{N}^{\circ} 34 / 2002$, de 11 de julio, de servicios de la sociedad de la información y del comercio electrónico: "El contrato se presume celebrado en el lugar en que se hizo la oferta" (artículo $1258 \mathrm{I}$ ); a menos que se trate de contratos celebrados a distancia con un consumidor, pues en tal caso, y como medida de protección, el contrato se considera celebrado en la residencia habitual de este último (artículo 1258 II). 
y no desde que el oferente ha recibido la aceptación (artículos 54 CCom. y 1262 CC. $)^{58}$. Sin embargo, la PACCom. destaca que el aspecto crucial para considerar constituida una relación contractual es el comportamiento de los contratantes, de modo que existirá contrato ahí donde la conducta de las partes demuestre, con suficiente certeza, la existencia de un acuerdo sobre

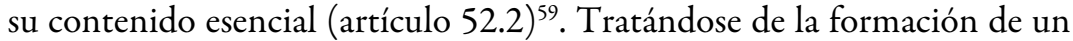
contrato entre ausentes, tal ocurrirá cuando la aceptación sea expedida, que es el modo en que la doctrina había interpretado el artículo 54 CCom. en su redacción anterior a la dada por la Ley $\mathrm{N}^{\circ} 34 / 2002$, de 11 de julio, de servicios de la sociedad de la información y del comercio electrónico ${ }^{60}$.

b) La segunda regla a destacar es la que se ofrece en el artículo 53.2 PACCom., que reputa oferta contractual (oferta ad incertam personam) el envío de catálogos, folletos o instrumentos similares efectuado a consumidores, a diferencia de lo que sucede cuando aquéllos se dirigen a otros destinatarios (que se considera una simple invitación a contratar o invitatio ad offerendum). Esta regla va más allá del criterio establecido por el artículo 20 de la Ley general de defensa de los consumidores y usuarios y por la jurisprudencia que lo ha aplicado (en su redacción anterior, recogida en el artículo 8 de la Ley $\mathrm{N}^{\circ} 26 / 1984$, de 19 de julio), merced del cual se había considerado que esa clase de declaraciones solamente tenía carácter contractual una vez celebrado el contrato con un consumidor concreto, pero no suponía que el empresa-

${ }^{58} \mathrm{El}$ artículo 1255 PMCC. altera el criterio actual del Código Civil, y establece que el contrato se considera perfecto desde el momento en que se hace efectiva la aceptación de la oferta, lo que sucede cuando ella llega al lugar que tenga designado para tal efecto el oferente o, en su defecto, a su establecimiento o domicilio (artículos 1250 y 1257). De esta forma, se acepta la interpretación que la doctrina venía dando al artículo 1262 CCEsp., en el sentido de que éste no acogía la teoría del conocimiento, como indica su tenor literal, sino la de la recepción, puesto que con ella era posible abarcar los casos en que aquél no se había producido por causas imputables al destinatario de la aceptación [Miranda Serrano, Las disposiciones del Código de Comercio", cit. (n. 46), p. 96]. Se elimina, a su vez, el criterio dualista presente en los actuales artículos 54 CComEsp. y 1262 CCEsp., conforme al cual se entiende que hay consentimiento desde que el oferente conoce la aceptación o desde que, habiéndola remitido el aceptante, no pueda ignorarla sin faltar a la buena fe".

${ }^{59}$ Irti, Natalino, Scambi senza accordo, en Rivista Trimestrale di Diritto e Procedura Civile, 52 (1998), pp. 347-364, aunque sin compartir el criterio, hace notar que el mercado avanza paulatinamente hacia un concepto de contrato entendido no como un acuerdo entre partes, sino como la coincidencia de actos unilaterales destinada a operar una finalidad económica de intercambio de bienes y servicios (supuesto que él designa con el nombre de contrato no consensual").

${ }^{60}$ Por todos, Miranda Serrano, Las disposiciones del Código de Comercio, cit. (n. 46), p. 97. 
rio estuviese obligado a contratar ${ }^{61}$. Con una interpretación semejante, se plantea necesariamente el problema del plazo durante el cual el empresario se encuentra obligado a concertar contratos en las condiciones publicitadas. El artículo 53.2 PACCom. soluciona ese inconveniente y, a la vez, deja claro que las reglas sobre contratos mercantiles no afectan una posible invocación de las normas sobre protección de los consumidores ${ }^{62}$.

c) La tercera regla digna de atención es la contenida en el artículo 54.7 PACCom., por la cual se diferencia aquella respuesta que comporta aceptación de la que origina una contraoferta. Esta norma establece que, si al contestar una oferta se acepta sustancialmente ésta (sin importar que en esa respuesta se introduzcan modificaciones no sustanciales), se considerará que existe aceptación, a menos que el oferente rechace esas modificaciones sin demora $^{63}$. A juicio de Bercovitz ${ }^{64}$, esta norma hace excepción al principio enunciado en el artículo 54.1 PACCom., según el cual "el silencio o la inacción, por sí solos, no constituirán aceptación”, pues con ella se pretende introducir una nueva regla en virtud de la cual, si la contraoferta es sustancialmente idéntica a la oferta, la buena fe exige responder. Con todo, a pesar de la mejora que esta norma supone en la materia, ella es todavía técnicamente mejorable. El problema que se observa en su texto estriba en el recurso al concepto de "modificaciones no sustanciales", que no viene definido por la PACCom. (como acaece, por ejemplo, en el artículo 19.2 CISG.), lo que introduce una cierta inseguridad en las partes al no saber si la aceptación dada origina o no el contrato que se proyecta celebrar (artículo 52.1 PACCom.).

\section{LA INTERPRETACIÓN DE LOS CONTRATOS MERCANTILES}

El actual artículo 57 CCom. une la interpretación del contrato mercantil con el deber de cumplirlo de buena fe. Así, para el código, una consecuencia de que los contratos se hayan de ejecutar y cumplir de buena fe es la observancia de los términos en que éstos fueron hechos y redactados, sin tergiversar con

${ }^{61}$ Ibíd., p. 83.

${ }^{62}$ Bercovitz Álvarez, Propuesta de Anteproyecto, cit. (n. 1), pp. 306-307.

${ }^{63} \mathrm{La}$ PMCC. va más allá todavía, y señala que el hecho de que las partes hayan dejado algún punto pendiente para negociaciones ulteriores no impide la perfección del contrato, si ellas están de acuerdo en sus elementos esenciales y quieren vincularse desde ese momento (artículo 1242). Por su parte, la regla del artículo 54.7 PACCom. se halla contemplada, con una redacción muy similar, en el artículo 1251 PMCC.

${ }^{64}$ Bercovitz Álvarez, Propuesta de Anteproyecto, cit. (n. 1), p. 307. 
interpretaciones arbitrarias el sentido recto, propio y usual de las palabras utilizadas $^{65}$.

Para la PACCom., en cambio, la interpretación de los contratos mercantiles se ha de realizar prestando mayor atención a la intención común de las partes que a la literalidad de las cláusulas (artículo 55.1). Para determinar esta intención común se acude al "ambiente general del contrato", especialmente relevante en las relaciones contractuales de larga duración, y que comprende los términos con que fue concebido (su contenido), las tratativas preliminares, las prácticas entre los contratantes, la conducta de éstos después de celebrado el contrato, la naturaleza y finalidad del mismo, y los usos y el sentido comúnmente dado a esos términos y expresiones en el respectivo sector de actividad económica (artículo 55.1 PACCom.). De esta forma, la PACCom. recoge la tradición común sobre la regla matriz en materia de interpretación (por ejemplo, artículos 1281 y 1282 CC.), pero presentada según la forma en que ha sido ofrecida por los textos de derecho uniforme (artículos 8 CISG., 4.1 y 4.2 PICC., 5:101 PECL., 39 ECC., II8:101 DCFR. y 5:101 PMCCR.). Si se quiere, el objetivo de esta regla es atender a una interpretación objetiva por referencia al mercado o tráfico empresarial, de suerte que las dudas que surjan respecto del sentido o alcance de un contrato mercantil se resuelvan otorgando prioridad a la significación que tengan en el tráfico las palabras, expresiones y términos utilizados por los contratantes ${ }^{66}$.

En sede de interpretación del contrato nuevamente vuelve a destacar la importancia del comportamiento de los contratantes. Para la PACCom., tanto las declaraciones como la conducta de las partes se han de interpretar conforme a su intención, al propósito práctico que se persigue con el contrato y al horizonte de comprensión del destinatario o, en su defecto, de acuerdo con el sentido que se les asigne en la práctica (artículo 55.2).

En este ámbito, es positiva la eliminación del actual artículo 59 del Código de Comercio, que establece una norma de cierre de imposible aplicación y cuya falta de congruencia con el artículo 50 ha sido denunciada suficientemente por la literatura especializada ${ }^{67}$. Según esta norma, si se originasen dudas en el proceso hermenéutico que no se puedan resolver con arreglo a lo establecido en el artículo 2 CCom., se decidirá la cuestión a favor del

${ }^{65}$ Miranda Serrano, Las disposiciones del Código de Comercio, cit. (n. 46), pp. 137-139.

${ }^{66}$ Ibíd., p. 140.

${ }^{67}$ Por todos, Bercovitz Álvarez, Propuesta de Anteproyecto, cit. (n. 1), p. 307; MARTÍn RodrígUeZ, La unificación civil y mercantil, cit. (n. 51), pp. 170-173 y 237238; Miranda Serrano, Las disposiciones del Código de Comercio, cit. (n. 46), pp. $140-142$. 
deudor. Esta solución difícilmente se puede producir, dado que este último artículo permite recurrir a las normas del Código Civil en la resolución de los conflictos mercantiles, entre las cuales existe una regla de clausura inconciliable con aquella que resuelve el asunto a favor del deudor. El artículo 1289 CC. establece, en efecto, que en los casos en que fuere absolutamente imposible resolver las dudas por las reglas establecidas en los artículos que lo preceden, si aquellas recaen sobre circunstancias accidentales del contrato, y éste fuere gratuito, tales se resolverán a favor de la menor transmisión de derechos e intereses. En cambio, si el contrato fuere oneroso, como sucede en los contratos mercantiles (artículos 1274 CC. y 1 y 2 CCom.), la duda se resolverá a favor de la mayor reciprocidad de intereses. Si las dudas recayesen, en fin, sobre el objeto principal del contrato, de suerte que no se pueda venir en conocimiento de cuál fue la intención o voluntad de los contratantes, el contrato será nulo. Como se trata de una norma de orden público, ella recibe aplicación preferente por sobre el artículo 59 del Código de Comercio, que contempla un efecto distinto al de la nulidad (artículo 6.3 CC.).

Las demás normas de esta sección cuarta son muy similares a las ya existentes en el Código Civil (artículos 1281-1289) y que ahora reciben una redacción mejorada en la PMCC (artículos 1278-1281) ${ }^{68}$. Así acaece, por ejemplo, con la regla del artículo 55.3 PACCom., que impide interpretar las cláusulas obscuras de un contrato a favor del que las hubiere establecido (artículos 1288 Cc. y 1280.2 PMCC.). A este respecto, quizá hubiese sido deseable, para conseguir una mayor conformidad entre el derecho interno español y el nuevo derecho de contratos, que la PACCom. diese cabida de forma expresa al principio de razonabilidad ${ }^{69}$, pese a que éste bien puede ser deducido del principio general de buena fe e, incluso más, muchas veces no resulta fácil distinguirlo conceptualmente de él ${ }^{70}$.

${ }^{68}$ El $§ 7$ del "Preámbulo" de la PACCom. reconoce expresamente que algunos de los principios recogidos en ella se hallan también expuestos en la legislación civil. La razón de esta reiteración estriba en que la disciplina ofrecida para los contratos mercantiles ha de tener una coherencia sistemática que permita su fácil aplicación. Además, todas las normas establecidas en el Código de Comercio aparecen indubitadamente como parte de la legislación mercantil, de manera que los participantes en el mercado tienen la seguridad formal de que tales normas son aplicables, como parte de dicha legislación especial, en todo el territorio español.

${ }^{69}$ Mencionado, por ejemplo, por ViCent Chuliá, Introducción, cit. (n. 36), p. 905.

${ }^{70}$ Miranda Serrano, Las disposiciones del Código de Comercio", cit. (n. 46), p. 142. 


\section{El CONTENIDO DEL CONTRATO MERCANTIL}

La sección quinta está dedicada al contenido del contrato mercantil, materia que queda dividida conceptualmente en dos partes: una referida al objeto y la causa (artículo 56) y otra al precio (artículo 57). La PMCC., en cambio, trata bajo el mismo epígrafe sobre el carácter contractualmente vinculante que poseen las afirmaciones o declaraciones efectuadas por un profesional en la publicidad o en las actividades de promoción de un producto o servicio (artículo 1276) y sobre la determinación del precio o de otra circunstancia relevante del contrato (artículo 1277). Por su parte, la causa viene regulada dentro de las disposiciones generales sobre los contratos (artículos 1238); mientras que el objeto queda sin una ubicación determinada, aunque existen referencias a él en diversas normas esparcidas por el libro IV (verbigracia, artículos 1088, 1279.2, 1303, 1308, 1310.1.1ํ y 1313).La razón de este tratamiento estriba en que este último elemento ha ido perdiendo predicamento a ojos de la doctrina, que lo considera confuso, innecesario e inútil ${ }^{71}$. Más que la existencia de un objeto del contrato, la atención en la actual formulación de la teoría del negocio jurídico se centra en garantizar que aquello sobre lo que recae el acuerdo cumpla con tres características configuradas como condiciones de su validez, a saber: posibilidad, licitud y determinación ${ }^{72}$.

a) En la primera parte de la sección, la PACCom. acude a la tradicional distinción entre contratos de obra y contratos de servicios, según si la obligación contractual consiste en la obtención de un resultado o en la prestación de los medios para alcanzarlo (artículo 56.1). La Propuesta se ocupa también de un problema no siempre de fácil solución, como es el establecimiento de los criterios para determinar la naturaleza del contrato cuando ésta no ha sido claramente señalada por las partes. En estos casos, habrá de tenerse en cuenta, además de la literalidad del contrato (artículo 55 PACCom.), otros aspectos relevantes, como el precio y los demás elementos de aquél, la dificultad de obtención de un resultado y las aptitudes de la parte que asume el encargo (artículo 56.2 PACCom.).

b) Esta sección trata asimismo de los criterios y medios de determinación del precio cuando éste no está fijado en el contrato ni se ha especificado el método a seguir para realizar tal determinación (artículo 57 PACCom.). En consideración al tipo de situación de que se trate, se establecen distintos

${ }^{71}$ Zweigert, Konrad - KöTz, Hein, An Introduction to Comparative Law (trad.

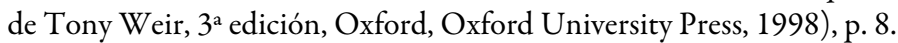

${ }^{72}$ Fajardo Fernández, Javier, Forma, objeto y causa/consideration, en CÁmARA LApuente, Sergio (coordinador), Derecho privado europeo (Madrid, Editorial Colex, 2003), pp. 404-405. 
parámetros para llevar adelante este empeño, a saber: $i$ ) el primero y más general de ellos es el recurso a los usos mercantiles de cada sector ("precio generalmente establecido"); ii) enseguida, cuando el precio ha de ser fijado por un tercero y éste no ha cumplido el encargo, la determinación se hará según la equidad ("precio razonable"); iii) por último, asumido que la relación contractual es de larga duración, el precio se puede determinar por analogía ("referencia equivalente más cercana"), si las referencias utilizadas para ese fin no existen, han desaparecido o son inaccesibles para las partes. Estos criterios hacen pensar que la determinación del precio siempre es posible, $y$ que una norma como el actual artículo 1447 CC. no tiene cabida, dado que ella declara ineficaz los contratos de compraventa cuyo precio ha sido dejado al arbitrio de un tercero y éste no quiere o no puede señalarlo ${ }^{73}$.

Se echa en falta, con todo, una referencia expresa a la buena fe como la existente en el actual artículo 57 CCom. y que la PMCC. ha mantenido en el artículo 1243, con la intención de recordar que el cumplimiento de un contrato incluye también "todas las consecuencias que, según su naturaleza, sean conformes a la buena fe, al uso y a la ley".

\section{El CUMplimiento del CONTRATO MERCANTIL}

Como regla básica de cumplimiento, la PACCom. asume que la relación contractual encarna una idea de cooperación entre las partes, quienes han contratado con miras a satisfacer determinados intereses que por sí mismoso por costos de oportunidad no pueden alcanzar aisladamente. Esa cooperación no constituye sólo una idea abstracta y desligada de la relación contractual concreta, sino que se vincula con el ámbito de lo razonablemente esperable (artículo 58.1 PACCom.) ${ }^{74}$. Esta idea, originalmente propuesta por Betti ${ }^{75}$ (1890-1968) como una base general del derecho de obligaciones, adquiere especial relevancia en las relaciones de larga duración y de red, por exigirse en ellas una especial dedicación de las partes al cumplimiento de las prestaciones en aras de la preservación de la propia relación contractual. Por eso,

${ }^{73}$ Bercovitz Álvarez, "Propuesta de Anteproyecto", cit. (n. 1), p. 308. El artículo 1277.2 PMCC. prevé un efecto distinto para este supuesto: cuando la determinación del precio o de otra circunstancia del contrato se haya dejado al arbitrio de un tercero y éste no quisiere o no pudiere hacerlo, los tribunales tienen la facultad para designar otra persona que le sustituya en tal cometido, siempre que la designación inicial no haya sido determinante para la celebración del contrato en tales condiciones.

${ }^{74}$ Véase los artículos 201 I del Contract Code; 5.1.3 PICC.; 76.1 ECC.; 1:202 PECL.; 7:104 ACQP.; 58.1 PACCom.; III-1:104 DCFR.; 1:104, 2:102, 3:102 y 5:103 PELSC.; 8:202 (2) PMCCR.

${ }^{75}$ BetTi, Emilio, Teoría general de las obligaciones (trad. de José Luis de los Mozos, Madrid, Editorial Revista de Derecho Privado, 1969), passim. 
se ha dicho con razón que los contratos de red se caracterizan por enlazar y armonizar en una misma relación jurídica dos fuerzas de sentido inverso, como son la cooperación y la competencia ${ }^{76}$.

Después de establecer este principio, el artículo 58 PACCom. trata sobre el momento en que se debe producir el cumplimiento (artículo 58.2), con especial mención de la forma de determinarlo cuando no ha sido señalado en el contrato (artículo 58.3) ${ }^{77}$; y de la facultad del deudor para cumplir en cualquier momento dentro del término contractualmente estipulado, a menos que el acreedor se hubiera reservado el derecho a elegir la oportuni-

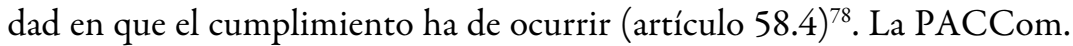
menciona también que el cumplimiento se rige por el principio de integridad de la prestación, salvo que el deudor ofrezca y el acreedor acepte un pago parcial (artículo 58.5) 79 . Constituyen una excepción a este principio aquellas relaciones contractuales prolongadas en el tiempo, ya por presentar una prestación de cumplimiento fraccionado, ya por importar un cumplimiento de tracto sucesivo, en las cuales se admite que la prestación sea ejecutada en parcialidades según la periodicidad acordada (artículo 58.5 PACCom.).

El artículo 59 PACCom. ofrece una regla de cumplimiento para las obligaciones recíprocas, según la cual las partes han de realizar sus prestaciones simultáneamente, a menos que de los términos del contrato resultare otra cosa. Se trata de una regla presente en la mayoría de los ordenamientos de de-

\footnotetext{
${ }^{76}$ CAFAg gi, Fabrizio, Contractual Networks and Small Businnes Act: Towards European Principles? en EUI Working Paper Law, 15 (2008), pp. 2-3.

${ }^{77} \mathrm{El}$ artículo 58.3 PACCom. altera el criterio del actual artículo 62 del Código de Comercio, que ha sido criticado por la doctrina por no adaptarse a las exigencias actuales del tráfico [Vicent Chuliá, Introducción, cit. (n. 36), p. 895]. Según éste, las obligaciones que no tuvieran prefijado un día por las partes o por las disposiciones del propio código serán exigibles diez días después de contraídas, salvo si llevan aparejada ejecución, en cuyo caso lo serán al día inmediato (cfr. artículos 63 I CCom. y 67 I PACCom.).

${ }^{78}$ La PMCC. da un tratamiento distinto a esta cuestión. Su artículo 1117 señala que será inmediatamente exigible la obligación que no tenga plazo de cumplimiento, ni quepa deducirlo de los usos; y que el término contractualmente estipulado se presumirá establecido en beneficio de ambas partes, a menos que del título de la obligación resultare otra cosa. Asimismo, la obligación sometida a un plazo cuya fijación dependa de la voluntad de una de las partes, dará derecho a la otra para requerirla a fin de que, de acuerdo con el título y las exigencias de la buena fe, lleve a cabo esa fijación. Si el requerimiento fuere desatendido, sin justa causa, la obligación se tendrá por vencida a partir del momento en que sea posible su cumplimiento, si así se hubiese expresado en el requerimiento. La misma regla se aplica cuando no hubiese plazo expreso, pero de la naturaleza y circunstancias de la obligación se dedujere que se ha querido conceder (artículo 1119 PMCC.).

${ }^{79}$ Véase el artículo 1161 PMCC.
} 
recho continental y de derecho uniforme destinada a consagrar la excepción de incumplimiento contractual (exceptio non adimpleti contractus) ${ }^{80}$. Sin embargo, hubiera sido preferible que la redacción ofrecida mirase el problema desde la exigibilidad de las prestaciones recíprocas, como lo hace, por ejemplo, el artículo 1591 del Code Civil de Québec (1994) ${ }^{81}$. Con la actual redacción, la regla establece más bien que la exigibilidad de las obligaciones recíprocas queda subordinada al principio de simultaneidad en el cumplimiento antes que al carácter de la prestación concreta que cada parte debe ejecutar, lo que induce a errores en la comprensión del mecanismo de funcionamiento de esta clase de obligaciones.

En efecto, la exigibilidad denota una cualidad de la relación obligatoria consistente en la convergencia de la facultad de exigir el cumplimiento y del deber de prestar ${ }^{82}$. Cuando falta cualquiera de esos extremos, la obligación permanece inexigible y no desencadena las consecuencias que de ese estado se derivan. A su vez, cuando la obligación ya ha devenido exigible, tal carácter puede cesar si concurre alguna de las causas a las que se atribuye esa virtud (la imposibilidad temporal de la prestación, la mora creditoris, la prescripción extintiva y, en general, la teoría de la inexigibilidad de la obligación). Dado que la exigibilidad es una cualidad de la relación obligatoria, ella se produce como efecto derivado de la forma en la que ésta ha sido contraída. Esto significa que aquélla procede de la configuración que las partes han dado a la eficacia de esa relación, y no del carácter unilateral o bilateral que pueda tener el contrato que le sirve de fuente. Por esta razón, la simultaneidad de cumplimiento no puede ser considerada un requisito de exigibilidad de las obligaciones derivadas de un contrato bilateral. Su operatividad sólo queda reservada para aquellos remedios ante el incumplimiento destinados

${ }^{80}$ Véase los artículos 1201 del Código Civil argentino; 533 del Código Civil japonés; 82 del Code des obligations de Suiza; 1460 del Codice Civile italiano; 374 del Código Civil griego; 428-431 del Código Civil português; 573 del Código Civil boliviano; 719 del Código Civil paraguayo; 6:262 NBW.; 476 del Código Civil Brasileiro; 71 CISG.; 7.1.3 PICC.; 9:201 PECL.; 108 ECC.; 1157 APC.; 8:304 ACQP.; III-3:401 DCFR.; 10:201 PMCCR.; 1191 PMCC.; 160 PRDC.; y los $\$ \$ 2: 609$ y 2:705 UCC. (cfr., además, $\$ \$ 2-508,2-608$ y 2-612 UCC), 237 del Restatement (Second) of Contract, 39 de la Sales of Goods Act del Reino Unido y 320 BGB.

${ }^{81}$ Artículo 1591 del Code Civil du Québec: "Lorsque les obligations résultant d’un contrat synallagmatique sont exigibles et que l une des parties n'exécute pas substantiellement la sienne ou n'offre pas de l' exécuter, l autre partie peut, dans une mesure correspondante, refuser d'exécuter son obligation corrélative, à moins qu'il ne résulte de la loi, de la volonté des parties ou des usages qu'elle soit tenue d'exécuter la première".

${ }^{82}$ Véase BARAONA GonZÁLEZ, Jorge, La exigibilidad de las obligaciones: noción y principales presupuestos (con especial énfasis en las cláusulas de aceleración), en Revista Chilena de Derecho, 24 (1997) 3, pp. 503-523. 
a restablecer el equilibrio patrimonial entre las partes, como acaece con la pretensión de cumplimiento y la indemnización de perjuicios.

\section{LA EXTINCIÓN DE LOS CONTRATOS DE LARGA DURACIÓN Y EL PROBLEMA DE LA EXCESIVA ONEROSIDAD SOBREVENIDA}

La sección séptima está dedicada a una forma particular extinción de los contratos de larga duración (1) y a los remedios a disposición del deudor cuando el cumplimiento de su prestación se torna excesivamente oneroso (2).

\section{La denuncia unilateral el contrato mercantil.}

El artículo 60 PACCom. se ocupa de la gravosa situación que puede significar para las partes un contrato por tiempo indefinido y en el que no se hubiera pactado la forma de darlo por terminado. En estos casos, en que la extinción convencional puede resultar imposible por la falta de voluntad de aquella parte que resulta beneficiada a costa del sacrificio patrimonial de la otra, se permite que cualquiera de los contratantes pueda dar por extinguido el contrato unilateralmente previa notificación a su contraparte dentro de un plazo razonable, con la consiguiente positivización de una regla ya consolidada en la jurisprudencia civil ${ }^{83}$. Al parecer, la realización de este preaviso da también por cumplido el requisito de buena fe exigido por dicha jurisprudencia ${ }^{84} \mathrm{y}$ al que se refiere expresamente el artículo 1121 PMCC.

El establecimiento de este derecho con carácter general es importante al momento de determinar las consecuencias de la apertura del concurso sobre los contratos mercantiles. El principio general en esta materia es que la declaración de concurso, por sí sola, no afecta la vigencia de los contratos con obligaciones recíprocas (artículos 61.1 y 61.2 de la Ley Concursal). Se hace excepción a él cuando la ley reconoce a las partes la posibilidad de ejercer la facultad de denuncia unilateral del contrato, la que no se ve afectada por la declaración del concurso (artículo 63.1 de la Ley concursal).

\section{El problema de la excesiva onerosidad sobrevenida.}

El artículo 61 PACCom. introduce una institución nueva dentro del derecho positivo español, hasta ahora reconocida sólo doctrinal y jurisprudencialmente, como es la condición desfavorable en que queda una de las partes si, durante la vigencia del contrato, el cumplimiento de su prestación de torna excesivamente oneroso.

\footnotetext{
${ }^{83}$ Bercovitz Álvarez, Propuesta de Anteproyecto, cit. (n. 1), p. 308.

${ }^{84}$ Ibíd., p. 308.
} 
Las relaciones de larga duración se pueden ver afectadas por un cambio en las circunstancias tenidas en cuenta al momento de contratar, las que vuelven excesivamente onerosa la ejecución de una de las prestaciones ${ }^{85}$. Cuando eso ocurre, la parte afectada no puede suspender el cumplimiento de su obligación, pero se le reconoce el derecho a solicitar sin demora la renegociación del contrato, expresando las razones en que se funda (artículo 61.1 I PACCom.). De esta forma, y siguiendo el principio de favor contractus que inspira el nuevo derecho de la contratación, la opción se decanta siempre por el conservación del contrato y la readecuación convencional de sus cláusulas, a diferencia de la primera solución ofrecida legislativamente a la excesiva onerosidad sobrevenida, que acordaba su resolución (artículos 1467 del Codice Civile italiano, 1198 del Código Civil argentino, 672 del Código Civil paraguayo y $478 \mathrm{del}$ Código Civil Brasileiro) ${ }^{86}$.

Ahora bien, si no se alcanza un acuerdo entre las partes, cualesquiera de ellas puede exigir a la instancia respectiva la adaptación del contrato para restablecer el equilibrio de las prestaciones o su extinción en una fecha determinada en los términos que al efecto se señalen (artículo 61.1 II PACCom.) ${ }^{87}$.

${ }^{85} \mathrm{Al}$ efecto, el artículo 61.2 PACCom. establece que: "existe excesiva onerosidad sobrevenida cuando, con posterioridad a la perfección del contrato, ocurran o sean conocidos sucesos que alteren fundamentalmente el equilibrio de las prestaciones, siempre que esos sucesos no hubieran podido preverse por la parte a la que perjudiquen, escapen al control de la misma y ésta no hubiera asumido el riesgo de tales sucesos".

${ }^{86}$ Siguen este mismo criterio el $\$ 313$ BGB. y los artículos 373 del Bundesgesetz über das Obligationenrecht suizo; 437 del Código Civil português; 6:258 NBW.; 6.2.3 PICC; 6:111 PECL.; 97.1 y 157 ECC.; 1135-1, 1135-2 y 1135-3 APC; 7:101 PMCCR.; III1:110 DCFR. y 101 PRDC. Con algunas diferencias, es también el principio del $\S$ 2-615 UCC (impracticability). Los artículos 1467 del Codice Civile italiano, 1198 del Código Civil argentino, 672 del Código Civil paraguayo y 479 del Código Civil Brasileiro permiten que la parte demandada de resolución por excesiva onerosidad sobrevenida enerve la acción ofreciendo una readecuación equitativa de las condiciones del contrato. El último de los códigos citados, sin embargo, establece que, si la excesiva onerosidad no comporta una ventaja desproporcionada para la otra parte, sólo cabe demandar su reducción o la modificación de las circunstancias según las cuales el contrato se debe ejecutar (artículo 480). Una postura intermedia a las dos anteriores ofrece el Código Civil griego, que faculta al juez para decidir si resuelve o readecúa el contrato que se ha tornado excesivamente oneroso (artículo 388).

${ }^{87}$ El mismo principio se establece en la ley 493 de la Compilación del Derecho civil foral de Navarra y ahora en el artículo 1213 PMCC. Sobre este último, véase SALVADOR CODERCH, Alteración de circunstancias, cit. (n. 2). 


\section{El INCUMPLIMIENTO DE LOS CONTRATOS MERCANTILES}

El Código Civil español no ofrece una exposición articulada de la responsabilidad contractual. Junto con el sistema general establecido bajo el título de De la naturaleza y efecto de las obligaciones (libro IV, título $1^{\circ}$, capítulo $2^{\circ}$ ), hay también diversos sistemas especiales, entre los que se encuentra aquel denominado de saneamiento (dentro de la disciplina del contrato de compraventa, aunque extensible a otros contratos). De esto se sigue que no exista tampoco un concepto unitario de incumplimiento. El concepto de tal que se utiliza es aplicable sólo al remedio indemnizatorio, por lo que no resulta extraño que la doctrina construyera éste en conexión con la culpabilidad del deudor (artículo 1001 CC. ${ }^{88}$. Paulatinamente, sin embargo, y por influencia de los textos de derecho uniforme, ha comenzado a existir consenso en torno a dos bases esenciales que se deben tener en cuenta a la hora de reconstruir dicho sistema desde el material normativo que fragmentariamente proporciona el Código Civil y otros cuerpos legales (por ejemplo, la Ley de Enjuiciamiento Civil respecto de la pretensión de cumplimiento).

La primera de ellas es que el incumplimiento carece de toda connotación subjetiva y se sitúa como el elemento material que integra el supuesto de cada uno de los mecanismos que el ordenamiento jurídico pone a disposición del acreedor para la protección de su derecho de crédito. Esta constatación permite comprender el incumplimiento desde dos perspectivas complementarias: como una infracción del programa de prestación que debe ejecutar el deudor y como una lesión del interés que el acreedor espera ver satisfecho con el contrato ${ }^{89}$. Si se unen ambos polos, aquél queda conceptualizado como cualquier desviación o perturbación del programa de prestación (o regla contractual) de la que se sigue una insatisfacción del interés del acreedor ${ }^{90}$. La relación obligatoria deja de estar referida, entonces, sólo a un orden de deberes de conducta propios del deudor, y se extiende también a la realización de unos resultados de satisfacción del interés del acreedor representados por la existencia o inexistencia de ciertos hechos, circunstancias o estados de la realidad

${ }^{88}$ Por todos, Castán Tobeñas, José, Derecho civil español, común y foral, III: Derecho de obligaciones (16 $16^{\mathrm{a}}$ ed. actualizada por Gabriel García Cantero, Madrid, Editorial Reus, 1992), pp. 235-288.

${ }^{89}$ Así, entre otros, BETTI, Teoría general de las obligaciones, cit. (n. 75), pp. 122-123.

${ }^{90}$ Véase, por todos, Morales Moreno, Antonio Manuel, Evolución del concepto de obligación en el derecho español (2005), ahora en EL MISMO, La modernización del Derecho de obligaciones (Madrid, Editorial Thomson-Civitas, 2006), pp. 29-30 y 36-38; Pantaleón Prieto, Fernando, Incumplimiento (D. Civil), en Enciclopedia Jurídica Básica (Madrid, Editorial Civitas, 1995), II, pp. 3507-3509. 
presupuestos por el contrato y garantizados por un contratante a favor del otro (cfr. \$241 II BGB.). Este doble contenido de la relación obligatoria hace que dogmáticamente sea más adecuado definir el incumplimiento como la falta de ejecución o realización de las exigencias del contrato ${ }^{91}$, formulación en la que confluyen las dos ideas antedichas. Tal es el criterio que inspira la definición de incumplimiento ofrecida por el artículo 1188 PMCC., mucho más amplia y objetiva que aquella que implícitamente se puede desprender del tratamiento dado a esta materia por la PACCom. ${ }^{92}$

La segunda de las bases mencionadas consiste, por su parte, en la articulación de un elenco articulado y coherente de remedios ante el incumplimiento contractual, destinado a superar el estado de insatisfacción del interés del acreedor que éste ha producido ${ }^{93}$. Desaparece así la diversificación de requisitos o efectos que se atribuye a determinadas modalidades de incumplimiento, permitiendo una mayor certeza del acreedor al momento de proteger su derecho de crédito. Para lograr ese objetivo, el nuevo sistema de responsabilidad contractual se asienta sobre un concepto material de incumplimiento que opera como el presupuesto de todos los remedios, función que aquél puede desempeñar sólo en la medida que se concibe con los elementos mínimos necesarios para aglutinar mecanismos de protección de finalidades diversas. Cada remedio concreto ha de tener, enseguida, su propio supuesto específico que se añade al genérico del incumplimiento en sentido material. Así ocurre especialmente en la facultad resolutoria (carácter esencial del incumplimiento) y en la indemnización de perjuicios (imputación subjetiva y objetiva del incumplimiento a la esfera de riesgo del deudor). En fin, la administración de este elenco de remedios se independiza de una prelación preestablecida y se entrega al acreedor, quien elegirá aquél que resulte más adecuado para satisfacer su interés, con la posibilidad de combinar cualquiera de ellos con la indemnización de los daños que ha sufrido y que no ha podido razonablemente mitigar ${ }^{94}$.

En el Código de Comercio español, el tratamiento del incumplimiento contractual es similar al recién descrito, con la diferencia de que no existe

${ }^{91}$ Morales Moreno, Antonio Manuel, Problemas que plantea la unificación del concepto de incumplimiento contractual, en BARros Bourie, Enrique - García Rubio, María Paz - Morales Moreno, Antonio, Derecho de daños (Madrid, Fundación Coloquio Jurídico Europeo, 2009), pp. 210-211.

${ }^{92}$ Véase los trabajos sobre la materia citados en la nota 2.

${ }^{93}$ Precursores en esta materia fueron PANTALEón PRIETo, Fernando, Las nuevas bases de la responsabilidad contractual, en Anuario de Derecho Civil, 46 (1993) 4, pp. 1719-1746; y Tallon, Denis, L'inexécution du contrat: pour une autre présentation, en Revue Trimestrielle de Droit Civil (1994) 2, pp. 223-238, cuyas ideas han influido en posteriores intentos de reelaboración del derecho del incumplimiento.

${ }^{94}$ Véase el artículo 1190 PMCC. 
en él ningún sistema general de responsabilidad, sino sólo referencias particulares para determinados contratos (verbigracia, el artículo 345 en lo que respecta a la evicción y el saneamiento a favor del comprador) y un reenvío de supletoriedad a las disposiciones del Código Civil merced de los artículos 2 y 50. Sólo a propósito de la cláusula penal hay una mención expresa en el actual artículo 56, según la cual el acreedor puede elegir entre la pena pactada o el cumplimiento forzoso del contrato, salvo que medie acuerdo en contrario. La PACCom. se hace cargo de esta ausencia de un tratamiento integral del incumplimiento contractual y ofrece una disciplina unitaria sobre él, adelantándose a la regulación general que ahora se incluye en la PMCC. Este régimen no contiene, empero, una definición de incumplimiento que sirva de supuesto de hecho genérico para todo el sistema de remedios, como sí ocurre en la PMCC. (artículo 1188). Aun así, y dado que la regulación del derecho del incumplimiento sigue las líneas dogmáticas del derecho uniforme, no existe obstáculo para aplicar a su respecto un concepto del tenor que antes se ha dado.

En la PACCom., las disposiciones de la sección octava se ocupan del factor de imputación del incumplimiento, de la garantía de cumplimiento y la resolución anticipada, de la subsanación del cumplimiento defectuoso, de la facultad resolutoria, y de la indemnización de perjuicios (5). Quedan fuera de su tratamiento, entonces, la pretensión de cumplimiento, sobre la cual la PMCC hace una regulación sustantiva mucho más ordenada que la actualmente existente en los artículos 1096-1099 CC., incluyendo en ella la pretensión del commodum repraesentationis del artículo 1186 (artículos 1192-1196); y la pretensión de reducción del precio (artículos 1197 y 1198 PMCC.).

\section{El factor de imputación del incumplimiento.}

El deudor no es responsable del incumplimiento que haya sido producido por una causa que no le sea imputable (artículo 62.2 PACCom.), concepto en el que quedan comprendidos aquellos incumplimientos causados por el acreedor o por cualquier evento cuyas consecuencias aquél no estaba obligado a asumir (artículo 61.1 PACCom.) ${ }^{95}$. Sin embargo, para que el deudor se pueda efectivamente liberar de responsabilidad, debe notificar a su contraparte de la existencia de aquella causa no imputable que le impide cumplir, y hacerlo dentro de un plazo razonable a partir del momento en que tuvo o pudo tener conocimiento de ella, so pena de quedar obligado al pago de los daños y perjuicios derivados de la falta de notificación (artículo 62.2 PACCom.). Dicha carga responde tanto a la idea de cooperación que subyace

${ }^{95}$ Véase el artículo 1188 PMCC. 
en la obligación (artículo 58.1 PACCom.) como al deseo de evitar que, en las relaciones de larga duración, el acreedor siga ejecutando su prestación o efectuando gastos que sólo redunden en un mayor perjuicio para él.

\section{La garantía de cumplimiento y la resolución anticipada.}

Asumiendo que las relaciones contractuales no son necesariamente de ejecución instantánea, la PACCom. recoge un mecanismo de protección del acreedor frente a supuestos en los que se teme la consumación de un incumplimiento esencial. Así, cuando uno de los contratantes tenga razones fundadas para creer que se producirá un incumplimiento esencial, puede exigir una garantía adecuada respecto de su cumplimiento y suspender entretanto su propia prestación (artículo 62.2 PACCom.). Si la garantía no se otorga, dicha parte tiene derecho a resolver el contrato (artículo 62.2 PACCom. $)^{96}$.

\section{La subsanación del cumplimiento defectuoso.}

La PACCom., acudiendo una vez más al principio de favor contractus, contempla la posibilidad de subsanación del cumplimiento defectuoso, salvo en los casos en que éste comporta un incumplimiento esencial que frustra definitivamente el interés del acreedor (artículo 63.1) ${ }^{97}$. Esta posibilidad es especialmente importante en los contratos de larga duración, porque supone que el incumplimiento de una de las prestaciones no necesariamente afecta la subsistencia del contrato, el que puede seguir cumpliendo los fines para los cuales fue celebrado. Coherente con el reconocimiento de esta facultad y con el principio de simultaneidad de cumplimiento recogido en el artículo 59 PACCom., se permite que la parte afectada suspenda su propia prestación mientras no se haya subsanado aquella que fue ejecutada defectuosamente (artículo 63.3 PACCom. $)^{98}$.

\section{La facultad resolutoria.}

La PACCom. dedica el artículo 64 al funcionamiento de la facultad resolutoria. Abre este régimen la definición de incumplimiento esencial, presupuesto necesario para que se pueda solicitar la resolución de un contrato (artículo 64.1 PACCom.) ${ }^{99}$. El concepto que de él se da recoge las ideas que

${ }^{96}$ Véase el artículo 1200 PMCC.

${ }^{97}$ Véase el artículo 1193 PMCC.

${ }^{98}$ Véase el artículo 1191 PMCC.

${ }^{99}$ El artículo 1199 PMCC. tiene una redacción más parca que el artículo 64.1 PACCom., y sólo se limita a señalar que la facultad resolutoria se puede ejercitar cuando existe un incumplimiento que, atendida su finalidad, haya de considerarse esencial, sin definir qué se entiende por tal. 
doctrinal y jurisprudencialmente se han elaborado al respecto, vale decir, que para determinar cuándo existe un incumplimiento esencial se debe atender tanto al resultado que ese incumplimiento produce en la relación contractual objetivamente considerada como a su particular gravedad o importancia económica, en ambos casos teniendo en cuenta cuál fue la distribución de riesgos que las partes previeron o pudieron prever al momento de contratar (fin de protección del contrato) ${ }^{100}$. Con clara referencia a los contratos de larga duración, una de las circunstancias que permite calificar un incumplimiento con tal intensidad es que la desviación del programa de prestación que él comporta determine una justificada pérdida de confianza sobre los cumplimientos futuros del deudor.

No obstante el carácter eminentemente judicial que se desprende del artículo 1124 CC., la jurisprudencia española ha permitido, como una medida de facilitación de la vida jurídica y económica (en razón de la finalidad que se atribuye a este remedio), que se pueda proceder a la resolución a través de una declaración extrajudicial del acreedor, sin perjuicio de que los tribunales puedan ejercer posteriormente una labor de control de las causas y efectos de la desvinculación así operada ${ }^{101}$. Consecuente con este modelo alternativo de resolución, la PACCom., a fin de agilizar liberación de las partes y permitir que puedan continuar ejerciendo su actividad económica por otros causes, disciplina el ejercicio extrajudicial de la facultad resolutoria como modelo único. Según su artículo 64.2, esta facultad se ejerce mediante una notificación dirigida a la otra parte dentro de un plazo razonable a partir del momento en que el contratante perjudicado tuvo o pudo tener cono-

${ }^{100}$ Véase los artículos 47 del Proyecto de Código franco-italiano de obligaciones y contratos; 1455 del Codice Civile italiano; 307 I del Contract Code; 25, 49.1 a) y 64.1 a) CISG;. 1604 II y III del Code Civil du Québec; 7.3.1 PICC.; 8:103 PECL.; 107 ECC.; 8:301 (2) ACQP.; 1158-1 I APC.; 10:301 (1) PMCCR.; III-3:502 DCFR.; 1199 I PMCC.; y 141 y 143 PRDC. (sólo respecto de la resolución ejercida extrajudicialmente). Implícitamente, también es el criterio seguido por el NBW. (artículo 6:265) y el BGB. (\$\$ 323 y 324$)$.

${ }^{101}$ Arija Soutullo, Carmen, Los efectos de la resolución del contrato por incumplimiento. Comentario de la STS 1 de julio 2005, en Revista de Derecho Patrimonial, 17 (2006), pp. 182-183; Clemente Meoro, Mario, La facultad de resolver los contratos por incumplimiento (Valencia, Editorial Tirant Lo Blanch, 1998), núm. 60-62, pp. 122-133; Díez-Picazo y Ponce de León, Luis, Fundamentos del Derecho civil patrimonial, II: Las relaciones obligatorias ( $6^{a}$ edición, Cizur Menor, Editorial Thomson-Civitas, 2008), pp. 813 y 840-841; Gómez Pomar, Fernando, El incumplimiento contractual en el derecho español, en InDret, 3 (2007), p. 30; Pantaleón Prieto, Las nuevas bases, cit. (n. 93), pp. 1731-1733; SAN Miguel Pradera, Lis Paula, Resolución por incumplimiento y modalidades de ejercicio (Madrid, Colegio de Registradores de la Propiedad y Mercantiles de España, 2004), núm. 365-650, pp. 305-514. 
cimiento del ofrecimiento tardío o del cumplimiento defectuoso ${ }^{102}$. Dicha forma de ejercicio se haya conectada con el plazo de cumplimiento que el acreedor puede conceder al deudor ("Nachfrist"). A tenor de lo dispuesto en el artículo 63.2 PACCom., en cualquier supuesto de incumplimiento, la parte perjudicada puede conceder a la otra un plazo razonable para que ejecute su prestación. Si trascurre ese plazo sin que el deudor cumpla, y sin importar que el incumplimiento no sea esencial, la parte perjudicada puede dar por terminado el contrato ${ }^{103}$.

Positivando un principio reconocido por la doctrina y la jurisprudencia para el contrato de suministro ${ }^{104}$, la PACCom. señala que los efectos derivados de la resolución de un contrato de ejecución continuada no comprenden la obligación de restituir las prestaciones realizadas con anterioridad, las que se tienen por legítimamente recibidas en contraprestación de lo que la parte afectada ha ejecutado a su vez (artículo 64.3) ${ }^{105}$.

La PACCom. es consciente de las consecuencias que la demora en la determinación de los efectos de la resolución puede provocar sobre la satisfacción del interés del contratante afectado, quien optará generalmente por realizar una operación de reemplazo que le permita continuar con el ejercicio normal de su actividad económica (artículo 66.1). En efecto, si bien la facultad resolutoria se ejerce mediante una notificación dirigida a la otra parte dentro de un plazo razonable a contar desde el momento en que la parte perjudicada tuvo o pudo tener conocimiento del incumplimiento (artículo 64.2 PACCom. $)^{106}$, lo cierto es que la tutela restitutoria e indemnizatoria derivada de la resolución requerirá, salvo casos calificados (verbigracia, que la pena acordada por las partes sea pagada voluntariamente por el deudor), de intervención judicial o arbitral. Se asume como premisa, pues, que las relaciones contractuales generalmente tienen fines a largo plazo, los que pueden ser alcanzados no solamente con el contrato incumplido, sino también acudiendo a otros agentes del mercado. Por eso, ante un incumplimiento esencial, la parte afectada puede recurrir a una operación de reemplazo siempre que

\footnotetext{
${ }^{102}$ Véase el artículo 1199 PMCC.

${ }^{103}$ Véase el artículo 1200 PMCC.

${ }^{104}$ Bercovitz Álvarez, Propuesta de Anteproyecto, cit. (n. 1), p. 309.

${ }^{105}$ Véase el artículo 1204 PMCC.

${ }^{106}$ En el derecho español, la resolución de un contrato mercantil se produce irre-
} mediablemente y de forma extrajudicial (arg. ex artículo 61 del Código de Comercio), a diferencia del régimen establecido para los contratos civiles en el artículo 1124 del Código Civil, que permite al juez señalar un plazo de gracia a favor del deudor y, en consecuencia, decidir la suerte final del contrato si aquél se ha opuesto a la facultad resolutoria ejercida por el acreedor. Véase Vicent Chuliá, Introducción, cit. (n. 36), p. 896, y la relación de la jurisprudencia que hace MARTín Rodríguez, La unificación civily mercantil, cit. (n. 51), pp. 120-123. 
lo haga en forma y plazo razonables después de la resolución del contrato; y en tal caso podrá exigir del contratante incumplidor la diferencia entre el precio del contrato y el precio de dicha operación, así como el resarcimiento de cualquier daño adicional (artículo 66.1 PACCom.) ${ }^{107}$.

A diferencia de lo que sucede con los artículos 1202 y 1203 PMCC., en la PACCom. no hay ninguna otra mención sobre la eficacia de la facultad resolutoria que aquella referida a los contratos de trato sucesivo (artículo 64.3). Además de ella, en esta última Propuesta sólo se señala que el ejercicio de este remedio no afecta las estipulaciones establecidas en el contrato para solucionar las controversias que surjan entre las partes, ni ninguna otra cláusula que regule sus derechos y obligaciones ante el evento de la resolución (artículo 64.2 PACCom.) ${ }^{108}$. La tipificación legal de esta regla permitirá que ésta pase a ser uno de los elementos de la naturaleza de los contratos mercantiles, haciendo innecesaria la inserción sistemática y repetitiva de una cláusula similar en cada uno de los contratos de esta clase ${ }^{109}$. En aplicación del principio de supletoriedad, los demás efectos de la resolución quedan sujetos a la legislación civil (artículos 2 CCom. y 50.2 PACCom.).

\section{La indemnización de perjuicios.}

La parte perjudicada por el incumplimiento tiene derecho a la reparación integral de los daños y perjuicios derivados de tal, salvo que éste sea excusable (artículo 65.1). Se recoge así una idea esencial a todo el sistema de protección del crédito, como es la posibilidad siempre presente de solicitar el resarcimiento del daño causado, con independencia del ejercicio de cualquier otro remedio (artículos 1190 y 1205 PMCC.). Sin embargo, y a diferencia de lo que ocurre en el artículo 1209 PMCC., en la PACCom. sólo se señala que el incumplimiento no autoriza a exigir una indemnización por los daños causados cuando aquél ha sido excusable, sin indicar cuándo se produce esa exoneración. Pese a esa preterición, no parece existir obstáculo para utilizar el mismo criterio, y entender que el incumplimiento es excusable cuando

${ }^{107}$ La PMCC. no se refiere expresamente a la determinación de la indemnización de perjuicios a partir de la operación de reemplazo que pueda haber celebrado el acreedor. Con independencia de que ella pueda efectivamente haber tenido lugar y servir al juez para la valoración posterior de los daños [como sugiere Vidal Olivares, $E l$ incumplimiento, cit. (n. 2), p. 289], no parece que su procedencia se desprenda sin más de la carga de mitigar las pérdidas que recoge el artículo 1211 PMCC., dado que las consecuencias son diversas en cada caso.

${ }^{108}$ Véase el artículo 1202 PMCC.

${ }^{109}$ Bercovitz Álvarez, Propuesta de Anteproyecto, cit. (n. 1), p. 309. 
se sitúa fuera de la esfera de riesgo que el deudor puede administrar (cfr. artículo 62.2 PACCom.) $)^{110}$.

Quizá el aspecto más interesante relacionado con la tutela indemnizatoria sea la determinación del interés a resarcir. A la hora de medir la extensión del resarcimiento debido en caso de incumplimiento contractual, existen dos alternativas: o bien se escoge como parámetro de referencia la situación económica que hipotéticamente existiría de haberse cumplido cabalmente el programa de prestación o, por el contrario, se opta por aquella que se verificaría de no haberse celebrado el contrato. La primera medida garantiza al acreedor la obtención de aquel beneficio que mediante la celebración del contrato pretendía lograr (interés contractual positivo o daño a la expectativa), en tanto que la segunda se endereza a la satisfacción de su interés de indemnidad (interés contractual negativo o daño a la confianza) ${ }^{111}$. Frente a un incumplimiento contractual está generalmente aceptada la preponderancia de la primera medida ${ }^{112}$, primacía que tiene su fundamento en la repercusión del incentivo sobre la celebración de compromisos que, como garante del beneficio esperado con el contrato, tiene aquélla sobre la segunda forma de determinación del montante indemnizatorio; y en la dificultad que supone reconstruir la situación en que se encontraba el patrimonio del contratante que padece el incumplimiento con anterioridad a la celebración del contrato ${ }^{113}$.

El artículo 65.2 PACCom. no hace mención alguna al interés a resarcir como consecuencia del incumplimiento, pero sí menciona que la extensión del daño contractual comprende cualquier pérdida sufrida (daño emergente) y cualquier ganancia de la que se haya visto privada la parte perjudicada (lucro cesante), así como los daños no pecuniarios que haya padecido (daño moral en sus distintas manifestaciones) ${ }^{114}$. Pese a esta preterición, no es aventurado suponer que los redactores tenían en mente un resarcimiento del acreedor en la medida del interés contractual positivo, en consonancia con los textos de derecho uniforme en los que aparece inspirada la PACCom..

${ }^{110}$ Pantaleón Prieto, Fernando, El sistema de responsabilidad contractual (materiales para un debate), en Anuario de Derecho Civil, 44 (1991) 3, pp. 10641065, llega a esta formulación a partir de los artículos 1105 y 1107 del Código Civil, interpretados sistemáticamente con el artículo 79 CISG.

${ }^{111}$ Soler Presas, Ana, La valoración del daño en el contrato de compraventa (Pamplona, Editorial Aranzadi, 1998), p. 82.

${ }^{112}$ El artículo 1203.3 PMCC. admite el resarcimiento del interés contractual negativo como umbral mínimo de la indemnización debida en caso de resolución por incumplimiento.

${ }^{113}$ Por todos, Soler, La valoración del daño, cit. (n. 111), p. 82.

${ }^{114}$ Véase el artículo 1207 PMCC. (aunque sin referencia al daño extrapatrimonial). 
Ahora bien, aunque la protección del interés contractual positivo se garantice con independencia del remedio escogido por el acreedor, ello no significa que en la determinación de su cuantía no deba influir el hecho de que éste retenga o recupere el valor de su propia prestación o resulte beneficiado de otra forma. Por eso, el artículo 65.2 PACCom. establece que, para la determinación del quantum indemnizatorio, se han de descontar las ventajas que la parte perjudicada haya obtenido y los gastos que haya evitado como consecuencia del incumplimiento.

En lo que atañe a la valoración del daño contractual, ésta se pude realizar de dos formas distintas: una abstracta, basada en un cálculo estimativo del daño sufrido por el acreedor (como acaece, por ejemplo, con la indemnización de los perjuicios moratorios en las obligaciones pecuniarias ${ }^{115}$ ); y otra concreta, que toma como referencia un negocio jurídico que se ha utilizado como paliativo del incumplimiento. La elección de una de ellas dependerá de la situación concreta de cada relación contractual, según si el acreedor ha optado o no por realizar una operación de reemplazo. Si la parte perjudicada por el incumplimiento ha celebrado una operación de esta especie, y siempre que lo haya hecho en forma y plazo razonables después de la resolución del contrato, la indemnización consistirá en la diferencia entre el precio del contrato y el precio del mentado negocio, sin perjuicio del derecho a ser resarcido de cualquier otro daño adicional (artículo 66.1 PACCom.) ${ }^{116}$. En caso contrario, la indemnización será equivalente a la diferencia entre el precio del contrato y el precio corriente al tiempo de su resolución, quedando comprendido también en ella el resarcimiento de cualquier otro daño adicional (artículo 65.3 PACCom.).

En fin, la determinación de la indemnización de perjuicios puede ser convenida por las partes, a través de la estipulación de una cláusula penal. Cuando aquéllas han acordado que el contratante incumplidor deberá pagar a la otra una suma determinada o determinable, el acreedor perjudicado por el incumplimiento tiene derecho al pago de esa suma sin tener que probar el daño y sin poder exigir, salvo que se establezca lo contrario, una suma mayor por el daño excedente (artículo 66.2 PACCom.). Si la pena fuera notoriamente desproporcionada al daño efectivamente sufrido, la suma convenida podrá ser morigerada por el juez (artículo 66.2 PACCom.). En esta materia,

${ }^{115}$ Véase los artículos 1108 CCEsp. y 1206 PMCC.

${ }^{116}$ Véase la nota 107.

${ }^{117}$ Para estos efectos, se considera como precio corriente en el mercado aquel generalmente cobrado por las mercancías o servicios contratados en circunstancias semejantes en el lugar en el que se debió haber cumplido el contrato o, de no existir precio corriente en esa plaza, el de otro lugar que parezca razonable tomar como referencia (artículo 65.3 PACCom). 
la PACCom. es innovadora, porque el Código Civil español, a semejanza del texto original del Code Civil francés (artículo $1231^{118}$ ), sólo permite la moderación de la pena cuando la obligación principal ha sido cumplida parcial o irregularmente por el deudor (artículo 1154), sin perjuicio de los intentos doctrinales y jurisprudenciales por extender también esta facultad a los supuestos en que se ha acordado una pena desproporcionada ${ }^{119}$.

Pese a que la regulación del incumplimiento en la PACCom. es considerablemente más extensa que la existente en el Código de Comercio, se echa en falta la regla del actual artículo 56, en virtud de la cual la parte perjudicada puede elegir alternativamente entre el cumplimiento forzoso del contrato y la pena estipulada. De todos modos, y aunque la referencia expresa no se encuentre entre las normas de la sección correspondiente, parece que esta opción continuará estando a disposición de la parte perjudicada (mas nunca del contratante incumplidor) ${ }^{120}$. En efecto, en lo no previsto por la legislación mercantil, seguirán siendo de aplicación subsidiaria los artículos 1152-1155 CC. ${ }^{121}$ sobre cláusula penal (artículos 2 CCom. 50.2 PACCom.), entre los cuales se encuentra una regla relativa a la mentada elección (artículo $1153)^{122}$.

\section{LA MOROSIDAD EN EL CUMPLIMIENTO ${ }^{123}$}

La sección novena está dedicada a la morosidad en el cumplimiento de los contratos mercantiles, operando la transposición orgánica de la Directiva 2000/35/CE del Parlamento Europeo y del Consejo, de 29 de junio de

${ }^{118}$ La Ley N ${ }^{\circ} 75 / 597$, de 9 de julio de 1975, modificó el Code Civil francés y permitió la moderación judicial de la cláusula penal si ésta es manifiestamente excesiva o irrisoria, reputándose no escrita cualquier estipulación en contrario (artículo 1152 II).

${ }^{119}$ Sobre ellos, véase CASTRO VítoREs, Germán, La cláusula penal ante la armonización del derecho contractual europeo (Madrid, Editorial Dykinson, 2009), pp. 87-107.

${ }^{120}$ Martín Rodríguez, La unificación civil y mercantil, cit. (n. 51), pp. 238239, destaca la coincidencia sustancial entre el tratamiento civil y mercantil de la cláusula penal.

${ }^{121}$ Véase los artículos 1146-1152 PMCC.

${ }^{122}$ Bercovitz Álvarez, Propuesta de Anteproyecto, cit. (n. 1), p. 309.

${ }^{123}$ La Ley $N^{\circ} 15 / 2010$, de 5 de julio, de modificación de la Ley 3/2004, de 29 de diciembre, de medidas de lucha contra la morosidad en las operaciones comerciales, introdujo algunos cambios relevantes en el régimen legal de los pagos originados en transacciones comerciales. Sin embargo, no alteró las disposiciones del Código de Comercio que guardan alguna relación con esa materia, por lo que las explicaciones que siguen conservan todavía su interés. Sobre esta ley, véase GómEZ LIGÜERRE, Carlos, El nuevo régimen de la morosidad en las obligaciones comerciales, en InDret, 4 (2011). 
2000, y que había sido recogida parcialmente en la Ley N $\mathrm{N}^{\circ} 3 / 2004$, de 29 de diciembre, que establece medidas de lucha contra dicho estado patrimonial. Esta forma de recepción resulta imprescindible, pues las normas de esa Directiva sólo tienen aplicación respecto de las operaciones mercantiles y, consecuencialmente, su sede idónea de tratamiento es la parte general que el Código de Comercio dedica a los contratos de esta especie ("Preámbulo", $\S$ 12). El objetivo de la PACCom. es, por consiguiente, ofrecer una regulación completa sobre la morosidad que pueda ser aplicada a todos los supuestos posibles, y no sólo a aquellos previstos en leyes especiales y en los que se observa una regulación fragmentaria y dispersa del fenómeno (verbigracia, la Ley $\mathrm{N}^{\circ}$ 3/2004 y el artículo 17 de la Ley $\mathrm{N}^{\circ} 7 / 1996$, de 15 de enero, de ordenación del comercio minorista). Además, la PACCom. ensancha el campo de aplicación de las normas sobre morosidad, ya que a diferencia de la mentada Directiva y de la Ley $\mathrm{N}^{\circ} 3 / 2004$ de transposición, que sólo atañen a los casos referidos al cumplimiento de obligaciones nacidas de operaciones realizadas entre empresarios y entre éstos y los poderes públicos, aquélla incluye también dos artículos de aplicación indistinta a empresarios y consumidores (artículos 68 y 69), quedando reservada el resto de la sección a los sujetos mencionados en la Directiva y en la ley de trasposición (artículos 70-73).

Esta sección tiene como pórtico un norma en la que se conservan los principios del actual artículo $63 \mathrm{CCom}$. sobre la fecha en que empieza la mora para el deudor ${ }^{124}$, con la especialidad prevista para los contratos de consumo, en los que no puede comenzar dicho estado si el consumidor no ha sido interpelado por escrito (artículo 67 PACCom.) ${ }^{125}$. La única innovación es la eliminación del carácter judicial (o notarial o público, en el caso de la protesta de daños y perjuicios) de la intimación que abre el estado de morosidad, para simplificar así los trámites que ha de realizar el acreedor en protección de su crédito. Desaparece, en cambio, la norma que es directa contrapartida de esta regla, como es aquella referida a la exigibilidad de las obligaciones mercantiles (artículo 62), y que comporta una de las más importantes diferencias con el régimen de las obligaciones civiles (artículo $1113 \mathrm{CC} .{ }^{126}$ ). Tal eliminación

${ }^{124} \mathrm{El}$ actual artículo 63 CComEsp. señala que la morosidad comienza: $i$ ) en las obligaciones que tuvieran día señalado para su cumplimiento por acuerdo de las partes o por disposición de la ley, al día siguiente de su vencimiento; ii) en los demás casos, desde el día en que el acreedor interpelare judicialmente al deudor o le intimare la protesta de daños y perjuicios hecha contra él ante un juez, notario u otro oficial público autorizado para admitirla.

${ }^{125}$ La PMCC. sólo se refiere a la determinación de la indemnización por retraso en el cumplimiento de una obligación pecuniaria (artículo 1206), y lo hace en términos similares a los empleados por el actual artículo 1108 CCEsp.

${ }^{126}$ Véase el artículo 1117 PMCC. 
es de agradecer, porque dicha norma muestra un criterio discordante con el del artículo 61 CCom., que proviene de la descoordinación habida en España entre las codificaciones civil y mercantil ${ }^{127}$. Esta discordancia explica que la jurisprudencia viniese aplicando la regla de exigibilidad inmediata de la obligación pura y simple contenida en el artículo 1113 CC., sin importar que se tratase de una obligación mercantil ${ }^{128}$.

En los artículos siguientes se establece que el derecho del acreedor a reclamar intereses legales desde la constitución en mora se extiende tanto sobre el importe de las deudas pecuniarias como sobre el valor de las no pecuniarias (artículo 68 PACCom.), e incluye también la reclamación de los gastos de cobro ocasionados por el retraso cuando éste sea imputable al deudor (artículo 69 PACCom.).

El artículo 70 PACCom. está dedicado a la morosidad de las obligaciones dinerarias surgidas de operaciones mercantiles realizadas entre empresarios o entre personas que actúen en el ejercicio de su actividad profesional, o entre éstos y los poderes públicos y que den lugar a la entrega de bienes o a la prestación de servicios. En esta clase de obligaciones se incurre en morosidad por el mero incumplimiento de los plazos de pago contractual o legalmente establecidos, y siempre que éstos no tengan el carácter de esencial ${ }^{129}$.

El plazo supletorio establecido por la PACCom. es siempre de treinta días, aunque el dies a quo varía dependiendo de que se produzca una u otra de las situaciones contempladas en su texto. De esta guisa, la morosidad se comenzará a computar desde que acaezca alguna de las siguientes situaciones: i) desde que se haya recibido la factura o una solicitud de pago equivalente; ii) desde la recepción de las mercaderías o prestación de los servicios, si algunos de esos documentos ofrece dudas; iii) desde la entrega de las mercaderías o de la prestación de los servicios, si el deudor recibe la factura o solicitud de pago equivalente antes que aquéllas o éstos; iv) desde la fecha de aceptación de los bienes o servicios, si por la ley o el contrato se ha dispuesto un procedimiento de aceptación o de comprobación de la conformidad de esos bienes o servicios ${ }^{130}$. Si bien no se distingue entre una prestación de ejecución única y otra fraccionada, lo cierto es que la importancia de esta norma está en su aplicación a las relaciones contractuales de larga duración, que suponen prestaciones que se ejecutan en el tiempo y que pueden ser, por tanto, incumplidas separadamente.

${ }^{127}$ Miranda Serrano, Las disposiciones del Código de Comercio, cit. (n. 46), pp. 162-163.

${ }^{128}$ Véase MARTín RodrígueZ, La unificación civil y mercantil, cit. (n. 51), pp. 127-130.

${ }^{129}$ Miranda Serrano, Las disposiciones del Código de Comercio, cit. (n. 46), p. 163.

${ }^{130}$ Con algunas variaciones de redacción, el artículo 70 PACCom. se corresponde con lo ya dispuesto en los artículos 4 y 5 de la vigente Ley $\mathrm{N}^{\circ} 3 / 2004$, de 29 de diciembre, sobre medidas de lucha contra la morosidad en las operaciones comerciales. 
Ahora bien, si el tipo de interés que debe pagar el deudor no estuviese expresamente estipulado en el contrato, el artículo 71 PACCom. señala que éste habrá ser aquel que se corresponda con la suma representada por el interés aplicado por el Banco Central Europeo a su más reciente operación principal de refinanciación, aumentado en siete puntos porcentuales ${ }^{131}$. Se trata de una penalización con clara intención disuasoria para el deudor moroso y, desde luego, muy superior a la establecida en otras normas de derecho español (verbigracia, el artículo 576 de la Ley de Enjuiciamiento Civil impone el interés legal más dos puntos en caso de mora procesal).

El artículo 72 PACCom. introduce en el Código de Comercio el concepto de cláusula abusiva que ya existía en el artículo 9 de la antes mencionada Ley $\mathrm{N}^{\circ} 3 / 2004$, la que puede ser invocada por el empresario acreedor cuando el deudor hubiese estipulado en el contrato unos plazos de pago o un tipo de interés moratorio muy distintos de los previstos subsidiariamente por la ley. Esta norma es peculiar, ya que contempla una excepción al principio vigente con la Ley $\mathrm{N}^{\circ} 3 / 2004$, en cuanto a que la invocación de la nulidad de una cláusula por su carácter abusivo queda reservada exclusivamente a los consumidores (antiguos artículos 10 bis de la Ley general de defensa de los consumidores y usuarios y 8.2 de la Ley sobre condiciones generales de contratación, hoy refundidos en el artículo 82.1 del texto de la Ley general de defensa de los consumidores y usuarios fijado por el Real Decreto Legislativo $\mathrm{N}^{\circ} 1 / 2007$, de 16 de noviembre). El propósito de esta disposición es favorecer con esta misma prerrogativa a los pequeños empresarios cuando contratan con las grandes empresas ${ }^{132}$.

La PACCom. establece asimismo una legitimación activa amplia, similar a la prevista en los artículos 9.4 de la Ley $\mathrm{N}^{\circ} 3 / 2004$ y 16 de la Ley $\mathrm{N}^{\circ}$ 7/1998, de 13 de abril, sobre condiciones generales de contratación, para solicitar la declaración judicial de nulidad de las cláusulas que, según sus prescripciones, resulten abusivas (artículo 72.2).

El artículo 73 PACCom. cierra esta sección novena y ofrece una norma novedosa destinada a reducir el costo de la reclamación judicial de deudas vencidas. Para ese efecto se señala que entre empresarios, profesionales y poderes públicos se puede ocurrir siempre conforme al proceso monitorio regulado en los artículos 812 y siguientes de la Ley de Enjuiciamiento Civil, sin que importe la cuantía de la deuda reclamada (que de otro modo no

${ }^{131}$ El artículo 71 PACCom. es coincidente con lo que actualmente prescribe el artículo 7 de la Ley $\mathrm{N}^{\circ}$ 3/2004, de 29 de diciembre, Sobre medidas de lucha contra la morosidad en las operaciones comerciales.

${ }^{132}$ Bercovitz Álvarez, Propuesta de Anteproyecto, cit. (n. 1), p. 310. 
podría superar los 30.000 euros, dado lo dispuesto en el artículo 812.1 de la Ley de Enjuiciamiento Civil ${ }^{133}$ ).

Como mirada de conjunto, la sección sobre la morosidad en el cumplimiento de los contratos mercantiles merece una valoración positiva, pues merced de ella se intentan generalizar ciertas medidas enderezadas a reducir sustancialmente un uso cada vez más habitual en las relaciones comerciales entre las grandes empresas y sus proveedores, como es la postergación de los pagos durante un largo tiempo. Con todo, para mejorar la técnica legislativa, sería conveniente que, de aprobarse la PACCom. (o el futuro Código Mercantil), se derogasen las normas redundantes previstas en las leyes especiales antes mencionadas, con el fin de potenciar la claridad de sus prescripciones y evitar posibles confusiones ${ }^{134}$.

Por último, cabe hacer notar que la PACCom. no contiene una prohibición sobre los plazos de gracia como la actualmente existente en el artículo 61 CCom., y que se ha mencionado siempre como una particularidad del derecho mercantil frente al derecho civil (concretamente, frente al artículo 1124 III CC. $)^{135}$. La cuestión no parece particularmente grave, sin embargo, por el tratamiento pormenorizado que se hace del funcionamiento de la resolución por incumplimiento en el artículo 64 PACCom. y por la interpretación que ha dado la jurisprudencia al artículo 1128 CC. ${ }^{136}$. Además, la Propuesta sólo impide que sea el juez quien otorgue un plazo de gracia, pero expresamente permite que el acreedor conceda al deudor un término razonable para que ejecute su prestación con posterioridad a la exigibilidad de la obligación (artículo 63.2).

\section{LA CESIÓN DE CRÉdITOS MERCANTILES}

La sección décima se ocupa de la cesión de créditos mercantiles realizada a título oneroso. Esto significa que las cesiones gratuitas quedan regidas por el Código Civil, aunque también esa disciplina se proyecte sobre las onerosas

${ }^{133} \mathrm{La}$ norma establece que se puede acudir al proceso monitorio siempre que se pretenda de otro el pago de una deuda dineraria, vencida y exigible, de cantidad determinada que no exceda de cinco millones de pesetas. La conversión que aquí se utiliza es la que figura en el anexo II del Real Decreto $N^{\circ} 1417 / 2001$, de 17 de diciembre, por el que se procede a la conversión a euros de las cuantías establecidas en la Ley de Enjuiciamiento Civil.

${ }^{134}$ Bercovitz Álvarez, Propuesta de Anteproyecto, cit. (n. 1), p. 311; Miranda Serrano, Las disposiciones del Código de Comercio, cit. (n. 46), pp. 169-170.

${ }^{135}$ Por todos, Miranda Serrano, Las disposiciones del Código de Comercio, cit. (n. 46), pp.159-161.

${ }^{136}$ Véase Martín Rodríguez, La unificación civil y mercantil, cit. (n. 51), pp. 114-120. 
en lo no previsto por el Código de Comercio (artículo 74.1 PACCom.). Las normas que rigen esta materia son similares a las establecidas para las transferencias de créditos no endosables en los actuales artículos 347 y 348 del Código de Comercio, que deberían quedar derogados si aquélla se convierte en ley. En ellas se dispone que la cesión no requiere del consentimiento del deudor (artículos 347 CCom. y 75.1 PACCom.) ${ }^{137}$, y que el cedente responde frente al cesionario de la existencia del crédito y de su titularidad, pero no de la solvencia del deudor, salvo que se hubiese pactado otra cosa o que -y en esto se sigue lo establecido en el artículo 1529 CC. - dicha insolvencia fuere notoria y anterior a la transferencia (artículos 348 CCom. y 77 PACCom.) ${ }^{138}$.

La PACCom. trata también de otras cuestiones, a saber: del tipo de créditos susceptibles de cesión (artículo 75), del alcance de la cesión de créditos con garantía (artículo 76), de la notificación al deudor de la cesión y de los efectos de esa notificación (artículo 78), y de las excepciones o la compensación que el deudor cedido puede oponer al cesionario (artículo 79) ${ }^{139}$. En lo que atañe a esta última cuestión, y recogiendo el principio del artículo 11 de la Ley $\mathrm{N}^{\circ} 7 / 1995$, de 23 de marzo, sobre crédito al consumo, se contempla una regla más favorable al deudor cuando éste ostenta la calidad de consumidor, como es la de la inderogabilidad de su derecho a oponer al cesionario las mismas excepciones y la compensación que hubiera podido alegar frente al cedente (artículos 79.2 y 79.4 PACCom.).

Hubiese sido deseable que la PACCom. contuviera una norma que permitiera la cesión del contrato mercantil con carácter general, sin limitar el cambio de posición jurídica a la tradicional figura de la cesión de créditos. Junto al principio de solidaridad de las obligaciones mercantiles (artículo 80) y la existencia de una regla sobre la producción de intereses moratorios desde el momento en que la obligación se hace exigible (artículo 71), reconocidos por la mentada Propuesta, la admisión expresa de la cesión de contrato era una de las materias que la doctrina echaba particularmente en falta ${ }^{140}$. Es de esperar que el Código Mercantil subsane esta omisión.

\section{LA SOLIDARIDAD EN LAS OBLIGACIONES MERCANTILES}

La sección décima trata de una característica ya consolidada de las obligaciones mercantiles, consistente en la presunción de solidaridad (“Preám-

${ }^{137}$ Véase el artículo 1215 PMCC.

${ }^{138}$ Véase los artículos 1218 y 1219 PMCC.

${ }^{139}$ Véase, respectivamente, los artículos $1214,1216,1220$ y 1221 PMCC. En ella, sin embargo, no se exige que la cesión sea notificada al deudor cedido, bastando para su eficacia el consentimiento del cedente y el cesionario (artículo 1215 PMCC).

${ }^{140}$ Martín Rodríguez, La unificación civil y mercantil, cit. (n. 51), p. 103. 
bulo", $₫ 14$ ), cuya ausencia era advertida por la doctrina ${ }^{141}$. Repitiendo el texto del artículo 100 del Código Comercial português (1888), la PACCom. dispone que en las obligaciones mercantiles se presume que los codeudores están obligados solidariamente, salvo pacto en contrario (artículo 80.1) ) $^{142}$. El artículo 80.2 agrega enseguida una regla imperativa ya formulada por la jurisprudencia del Tribunal Supremo ${ }^{143}$ (aunque con críticas por parte de la doctrin $\mathrm{a}^{144}$ ) y que se encuentra recogida en términos casi literales en el artículo 101 del Código Comercial Português, como es aquella que atañe a la responsabilidad solidaria que tiene el fiador de una obligación mercantil junto al afianzado (cfr. artículo $439 \mathrm{CCom}$. $)^{145}$. Ambas reglas se explican por la función económica que desempeña la solidaridad, enderezada a conseguir un refuerzo de la garantía patrimonial de que goza el acreedor (artículos 1911 CC. y 1089 PMCC), de forma muy similar a como lo hacen las garantías personales ${ }^{146}$.

${ }^{141}$ Así, entre otros, Miranda Serrano, Las disposiciones del Código de Comercio, cit. (n. 46), pp. 172-173; ViCENT Chuliá, Introducción, cit. (n. 36), p. 893.

${ }^{142} \mathrm{El}$ artículo $1122 \mathrm{PMCC}$. establece un principio idéntico, pero con carácter general. Según éste, cuando en virtud de un mismo contrato dos o más personas sean deudoras de una misma prestación que cualquiera pueda realizar íntegramente, todas ellas quedan obligadas solidariamente, salvo que se pueda concluir lo contrario de la ley o del contenido del contrato. Esta regla no es aplicable, sin embargo, si los deudores lo son en virtud de un contrato celebrado con un profesional y en el que han actuado como consumidores o usuarios.

${ }^{143}$ Bercovitz Álvarez, Propuesta de Anteproyecto, cit. (n. 1), pp. 311-312.

${ }^{144}$ Vicent Chuliá, Introducción, cit. (n. 36), p. 893, por ejemplo, considera que las sentencias del Tribunal Supremo español que han acogido este criterio comportan una doctrina arbitraria y sin fundamento legal, que bien se puede extender a otras obligaciones mercantiles, con la consiguiente extralimitación de la función del juez, que se convierte en legislador.

${ }^{145}$ En el Código de Comercio español, la fianza mercantil es gratuita, salvo que medie pacto en contrario (artículo 441). Si existiera allí una norma como el artículo 1522 del Código Civil chileno, esa gratuidad tendría influencia en la fase de contribución a la deuda, para determinar si el fiador ha tenido o no interés en la extinción de la obligación. El artículo 1145 del Código Civil español, en cambio, se decanta por un criterio uniforme, y señala que el codeudor que ha hecho el pago sólo puede reclamar de sus codeudores la parte que a cada uno corresponda, con los intereses del anticipo. El artículo 1135 PMCC. varía esta regla y establece que el codeudor que ha pagado puede o bien $i$ ) reclamar de los demás, en la parte que a cada uno corresponda, el reembolso de las cantidades aplicadas a aquel fin, los gastos razonablemente causados y los intereses de unas y otros; o $i$ i) subrogarse en los derechos del acreedor para exigir a cada uno de los codeudores la parte que corresponda.

${ }^{146}$ Díez-Picazo y Ponce de León, Fundamentos, cit. (n. 101), II, p. 238. 


\section{LA PRESCRIPCIÓN DE LAS ACCIONES MERCANTILES}

La PACCom. también se propone remozar la actual regulación de la prescripción contenida en el título II del libro IV CCom., referida principalmente a las distintas clases de acciones derivadas de los actos de comercio y sus formas y plazos de prescripción, y a ello dedica los artículos 942- 952. Por las funciones que cumple, esta materia ha estado presente no sólo en los esfuerzos de unificación del derecho europeo (capítulo $10^{\circ}$ PICC.; artículos 88.4, 129 y 134-136 ECC.; capítulo $14^{\circ}$ PECL.; libro III, capítulo $7^{\circ}$ DCFR. ${ }^{147}$ ), sino también en las reformas de los derechos nacionales. Así ha ocurrido, por ejemplo, en Alemania ${ }^{148}$, Francia ${ }^{149} \mathrm{y}$, aunque de forma muy mínima, en la PMCC. ${ }^{150}$.

$\mathrm{Al}$ respecto, el régimen general ofrecido para la prescripción intenta ofrecer un conjunto sistemático y completo de normas sobre la institución, ausente en el Código de Comercio ${ }^{151}$. Esta disciplina queda compuesta de varios principios de general aceptación, a saber: $i)$ se establece el carácter no modificable de los correspondientes plazos legales (artículo 942 PACCom.); ii) se permite la renuncia a su invocación a posteriori, pero nunca de forma anticipada, afectando en todo caso esa renuncia solamente al renunciante y no a sus codeudores (artículo 943 PACCom.); iii) se señala

${ }^{147}$ Sobre estos dos últimos, véase Domínguez Luelmo, Andrés - Álvarez ÁlVAREZ, Henar, La prescripción en los PECL. y en el DCFR., en InDret, 3 (2009).

${ }^{148} \mathrm{El}$ capítulo V del libro I del BGB., relativo a la prescripción (Verjährung), fue completamente reformado por la Ley de modernización del Derecho de obligaciones (Gesetz zur Modernisierung des Schuldrechts), de 26 de noviembre de 2001. Posteriormente, se promulgaron la Ley de adaptación de las disposiciones sobre prescripción a la Ley de modernización del Derecho de obligaciones (Gesetz zur Anpassung von Verjährungsvorschriften an das Gesetz zur Modernisierung des Schuldrechts), de 9 de diciembre de 2004, que complementa el régimen de la prescripción establecido en 2001; y la Ley de modificación del Derecho de sucesiones y de la prescripción (Gesetz zur Änderung des Erb-und Verjährungsrechts), de 24 de septiembre de 2004, que incide sobre la prescripción de las pretensiones familiares y sucesorias.

${ }^{149}$ De momento, sólo se ha legislado respecto de la segunda parte de la modernización del derecho privado francés contenida en el Avant-Projet de reforme du Droit des obligations et du Droit du la prescription (APC, 2005). Fruto de ello es la Ley $\mathrm{N}^{\circ}$ $561 / 2008$, de 17 de junio de 2008, por la que se reforma el régimen de la prescripción adquisitiva y extintiva en materia civil (artículos 2219-2254 del Code Civil, más algunas modificaciones en otros artículos de ese código y de ciertas leyes especiales).

${ }^{150}$ En verdad, la PMCC. sólo modifica el artículo 1974, que queda redactado de la siguiente forma: La interrupción de la prescripción de acciones en las obligaciones solidarias con pluralidad de acreedores aprovech a por igual a todos ellos.

${ }^{151}$ Miranda Serrano, Las disposiciones del Código de Comercio, cit. (n. 46), p. 175 . 
que la prescripción no puede ser declarada de oficio por el juez (artículo 944 PACCom.); y iv) se contempla un plazo único de prescripción de tres años que regirá de forma general, salvo que una norma especial disponga un lapso distinto (artículo 945 PACCom.). Esta última regla constituye un cambio sustancial respecto de la situación actualmente existente. Hoy en día, si el Código de Comercio no fija un plazo de prescripción para una determinada reclamación, se ha de acudir, en virtud de la remisión del artículo 943, a los términos indicados en el Código Civil (artículos 1962-1968), lo que provoca algunos inconvenientes, por ejemplo, en materia de responsabilidad de los administradores sociales ${ }^{152}$.

Además, en la regulación ofrecida por la PACCom. se señalan los criterios para el cómputo de los plazos (artículos 946 y 947), y se trata de otras cuestiones que atañen a la prescripción de las acciones para reclamar el cumplimiento de obligaciones que suponen pagos periódicos (artículo 948), o bien intereses o prestaciones accesorias (artículo 949). Respecto de ellas, rige un criterio de independencia, que trae consigo que el plazo de prescripción se cuente desde el día de la exigibilidad de aquellas prestaciones que han sido incumplidas, sin perjuicio de que se hayan efectuado posteriormente otras prestaciones diversas (artículo 948.2 PACCom.); y que la prescripción de las acciones para reclamar el cumplimiento de intereses o de prestaciones accesorias no afecte la del crédito principal (artículo 949.2 PACCom.), pero que no suceda lo mismo cuando lo que ha prescrito es la acción enderezada a exigir este último (artículo 949.1 PACCom.).

Los artículos 950-952 PACCom. prevén las reglas sobre interrupción y suspensión del plazo de prescripción, destacando el acercamiento del régimen mercantil al civil en lo referente a las causas por las que aquél se ve afectado. El nuevo artículo 950 señala que el plazo de prescripción se puede interrumpir, por una sola vez, mediante la reclamación extrajudicial de la deuda instada por el acreedor, admitiendo de esta forma la causa prevista en el artículo 1973 CC. y en la jurisprudencia ${ }^{153}$, aunque con la limitación recién mencionada: sólo se puede hacer uso de ella por una sola vez. Por lo demás, las causas de interrupción siguen siendo idénticas a las mencionadas en el

${ }^{152}$ El problema lo ha provocado la redacción del actual artículo 949 del Código de Comercio, que pareciera dar a entender que la prescripción de la acción dirigida contra los socios gerentes y los administradores sociales sólo comienza cuando éstos han cesado en su cargo y que toda responsabilidad prescribe a los cuatro años de producido este hecho. Además, se duda si ese plazo rige tanto para la acción social de responsabilidad (artículo 238 de la Ley de sociedades de capital) como para la acción individual (artículo 241 de la Ley de sociedades de capital).

${ }^{153} \mathrm{Al}$ respecto, Miranda Serrano, Las disposiciones del Código de Comercio, cit. (n. 46), pp. 176-178. 
artículo 944 CCom. (demanda o cualquier género de interpelación judicial hecha al deudor, y reconocimiento de la obligación). Sólo se omite la renovación del documento en que se funde el derecho del acreedor, que parece, empero, una aplicación obvia y bien cabe considerarla como una modalidad del reconocimiento de deuda ${ }^{154}$. Por último, en el artículo 951 PACCom. están contenidas las reglas sobre la reanudación del plazo de prescripción interrumpido; y en el artículo 952 PACCom. la posibilidad de suspensión automática de dicho plazo en supuestos excepcionales de fuerza mayor que impidan al acreedor reclamar su derecho de crédito.

\section{LA CADUCIDAD DE LOS DERECHOS DE CARÁCTER MERCANTIL}

Para acabar, entre los artículos 953 y 955 PACCom. se regula la caducidad de los derechos surgidos de las relaciones jurídicas de carácter mercantil, estableciéndose una interesante distinción entre los plazos de origen legal y convencional (artículo 953 PACCom.). Esta distinción comporta algunas consecuencias prácticas importantes, sobre todo en relación con la renuncia por parte del acreedor (artículo 954.1 PACCom.), con la facultad de revisión judicial de los plazos fijados convencionalmente si fuesen excesivamente breves (artículo 954.2 PACCom.) y con la posibilidad de invocación de oficio de la caducidad, que no existe respecto de los supuestos convencionales (artículo 955 PACCom.) ${ }^{155}$.

\section{UNA VALORACIÓN COMPARATIVA A MODO DE CONCLUSIÓN}

Sin duda, la PACCom. constituye un importante paso en el proceso de modernización del derecho español de obligaciones, cuyo ejemplo será seguido por la ya concluida disciplina sobre los contratos mercantiles que se incluirá en el Código Mercantil en el que actualmente trabaja la Comisión General de Codificación.

Pese a los méritos dogmáticos que comportan la reforma y actualización de ciertas instituciones, reglas y principios de la contratación mercantil, el procedimiento utilizado para operar tales cambios no parece el más indicado. En efecto, la solución que en mejor modo contribuiría a lograr una racionalización del derecho privado español es el desplazamiento de toda la parte general de los contratos mercantiles al Código Civil, como ha hecho la PMCC. De esta forma, el Código de Comercio (o su sucesor, el Código

\footnotetext{
${ }^{154}$ Bercovitz Álvarez, Propuesta de Anteproyecto, cit. (n. 1), p. 312.

${ }^{155}$ Ibíd., p. 313.
} 
Mercantil) quedaría integrada sólo por el tratamiento particular de los contratos mercantiles y por las demás materias propias de esta parcela del derecho, que se hallan dotadas de una autonomía tanto formal como sustancial $^{156}$. La tendencia generalizada en la doctrina mercantilista es favorable a esta emigración al Código Civil de las reglas especiales nacidas en el tráfico mercantil, algunas con reconocimiento positivo y otras contenidas en la jurisprudencia de los tribunales superiores de justicia, por considerar que ni son tan especiales como para justificar una sede propia, ni en muchos casos establecen algo distinto a lo preceptuado por el Código Civil ${ }^{157}$. Es más, su generalización y objetivación ha hecho que estas mismas reglas hayan sido utilizadas en el ámbito civil e, incluso más, hayan recibido en él un reconocimiento legislativo.

A ello se suma que los contratos mercantiles no constituyen un tipo contractual en sentido propio, pues todas las normas que componen su teoría general están contenidas en el Código Civily, por consiguiente, no dan lugar a un modelo de regulación típico y uniforme ${ }^{158}$. En España, la existencia de un título especial con ciertas normas especiales sobre ellos se explica por una razón histórica concreta. Producto de los obstáculos que los derechos forales imponían a la codificación civil, la redacción del primer Código de Comercio (1829) fue una labor de más fácil acometimiento. Los veinte artículos que este código dedicaba a los contratos (artículos 243-263) no respondían al deseo del legislador de recoger determinadas especialidades de éstos o de las obligaciones mercantiles que a través de la costumbre venían generándose desde la Edad Media. Su propósito fue más ambicioso y de mayor alcance, pues consistía en tratar de contrarrestar las inseguridades que para el tráfico comercial suponían el derecho por ese entonces vigente mediante la inclusión en el Código de Comercio de normas propiamente civiles ${ }^{159}$. Esas normas, con algunas refundiciones y modificaciones de estilo, pasaron después al código

${ }^{156}$ Engrácia Antunes, José A., Direito dos contratos comerciais (Coimbra, Edições Almedina, 2009), p. 84, menciona que la contratación mercantil posee una doble autonomía dogmática. Ante todo, esta autonomía es formal, dado que la ley disciplina de forma separada una serie de contratos mercantiles mediante un elenco propio (tipicidad de configuración) y extenso (tipicidad de regulación). Pero ella es también sustancial, sobre todo teniendo en cuenta el crecimiento exponencial de las figuras contractuales mercantiles, su relevo dentro del tráfico mercantil contemporáneo y la densidad y complejidad de su marco regulatorio.

${ }^{157}$ Por todos, Martín Rodríguez, La unificación civil y mercantil, cit. (n. 51), pp. 186-203 y 223-224; Miranda SERrano, La contratación mercantil, cit. (n. 35), pp. 40-46.

${ }^{158}$ Engrácia Antunes, Direito dos contratos comerciais, cit. (n. 156), pp. 85 y 88;

Miranda Serrano, La contratación mercantil, cit. (n. 35), pp. 25-27.

${ }^{159}$ Miranda Serrano, La contratación mercantil, cit. (n. 35), p. 30. 
de 1885 (libro I, título $4^{\circ}$, artículos 50-63), y sólo desde la promulgación del Código Civil en 1889 comenzaron a ser vistas como especialidades mercantiles (cuando, en verdad, sólo algunas lo eran, como acaece con la prohibición de fijar términos de gracia o la exigibilidad de las obligaciones puras y simples).

De ahí que la decisión más coherente con la actual conformación del derecho mercantil fundado en diversos niveles de regulación y racionalización normativa sea disciplinar la teoría general del contrato íntegramente en el Código Civil, reservando para el Código de Comercio (o el futuro Código Mercantil) el tratamiento de distintos conjuntos normativos de aplicación sectorial, esto es, aquellos cuya aplicación se circunscribe a grupos o cadenas de contratos mercantiles que son específicos de determinadas actividades comerciales $^{160}$.

\section{BIBLIOGRAFÍA}

Albiez Dohrmann, Klaus Jochen (director), Derecho privado europeo y modernización del Derecho contractual en España (Barcelona, Atelier libros, 2011).

ÁNGEL YAGÜEZ, Ricardo, Lealtad en el período precontractual (la conducta de las partes en las negociaciones preliminares, según proyectos de Derecho contractual europeo y conforme a otros trabajos prelegislativos), en Anuario de Derecho Civil, 63 (2010) 3.

ARANA DE LA FuENTE, Isabel, Algunas precisiones sobre la reforma de la cláusula penal en la Propuesta de modernización del Código Civil en materia de obligaciones y contratos, en InDret, 4 (2010).

Arija Soutullo, Carmen, Los efectos de la resolución del contrato por incumplimiento. Comentario de la STS 1 de julio 2005, en Revista de Derecho Patrimonial, 17 (2006).

BARAONA GonzÁlez, Jorge, La exigibilidad de las obligaciones: noción y principales presupuestos (con especial énfasis en las cláusulas de aceleración), en Revista Chilena de Derecho, 24 (1997) 3.

Barrientos Zamorano, Marcelo, Daños y deberes en las tratativas preliminares de un contrato (Santiago, LegalPublishing, 2008).

Bercovitz Álvarez, Rafael, Propuesta de Anteproyecto de Ley de modificación del Código de Comercio en la parte general sobre contratos mercantiles y sobre prescripción y caducidad, en Revista de Derecho Bancario y Bursátil, 102 (2006).

BetTi, Emilio, Teoría general de las obligaciones (trad. de José Luis De los Mozos, Madrid, Editorial Revista de Derecho Privado, 1969).

CAFAggi, Fabrizio, Contractual Networks and Small Business Act: Towards European Principles? en EUI Working Paper Law, 15 (2008).

Castán Tobeñas, José, Derecho civil español, común y foral, III: Derecho de obligaciones (16 ed. actualizada por Gabriel García Cantero, Madrid, Editorial Reus, 1992).

Castro Vítores, Germán, La cláusula penal ante la armonización del derecho contractual europeo, Madrid, Editorial Dykinson, 2009.

${ }^{160}$ Engrácia Antunes, Direito dos contratos comerciais, cit. (n. 156), p. 88. 
Clemente Meoro, Mario, La facultad de resolver los contratos por incumplimiento (Valencia, Editorial Tirant Lo Blanch, 1998).

Comisión General de Codificación, Propuesta de Anteproyecto de Ley de contratos de distribución. Memoria explicativa del Borrador de Anteproyecto de Ley de contratos de distribución, en Revista de Derecho de la Competencia y la Distribución, 2 (2008).

De la Cámara Álvarez, Manuel, Comentarios al Anteproyecto o Propuesta de Código de Sociedades Mercantiles, en Delgado de Miguel, Juan Francisco (coordinador), Instituciones de derecho privado, VI,2: Derecho de sociedades. Parte especial (Madrid, Editorial Civitas, 2004) = Delgado De Miguel, Juan Francisco (coordinador), Instituciones de Derecho privado, VI, 5: Derecho mercantil especial (Madrid, Editorial Civitas, 2005).

Díez-Picazo y Ponce de León, Luis, Reforma de los códigos y Derecho europeo, en Anuario de Derecho Civil, 56 (2003) 4.

Díez-Picazo y Ponce de León, Luis, Fundamentos del Derecho civil patrimonial, II: Las relaciones obligatorias ( $6^{a}$ edición, Cizur Menor, Editorial Thomson-Civitas, 2008).

Domínguez luelmo, Andrés - Álvarez Álvarez, Henar, La prescripción en los PECL y en el DCFR, en InDret, 3 (2009).

Embid Irujo, José Miguel, La regulación de los grupos en la Propuesta de Código de Sociedades Mercantiles, en VV. AA., Estudios de Derecho de sociedades y Derecho concursal. libro homenaje al profesor Rafael Garcia Villaverde (Madrid, Marcial Pons Ediciones Jurídicas y Sociales, 2007), I.

Embid Irujo, José Miguel, Notas sobre el régimen jurídico de las entidades sin ánimo de lucro, su estructura interna y la responsabilidad de los órganos gestores (especial referencia a las fundaciones), en Revista Valenciana de Economía y Hacienda, 7 (2003).

Engrácia Antunes, José A., Direito dos contratos comerciais (Coimbra, Edições Almedina, 2009).FAJARDo FERNÁNDEZ, Javier, Forma, objeto, y causa/consideration, en Cámara Lapuente, Sergio (coordinador), Derecho privado europeo (Madrid, Editorial Colex, 2003).

Fenoy Picón, Nieves, El incumplimiento contractual y sus remedios en la Propuesta española de modernización del Código Civil de 2009, en DE la MAZa Gazmuri, Íñigo (coordinador), Cuadernos de análisis jurídico. Colección Derecho privado, VII: El incumplimiento contractual. Nuevas perspectivas (Santiago, Ediciones de la Universidad Diego Portales, 2011) [en prensa].

Fenoy Picón, Nieves, La modernización del régimen del incumplimiento del contrato: propuestas de la Comisión General de Codificación. Primera parte: aspectos generales. El incumplimiento, en Anuario de Derecho Civil LXIII (2010) 1.

Galicia Aizpurua, Gorka H., Causa de la obligación frente a causa del contrato en el Código Civil español: una exposición critica (a propósito de la Propuesta de modernización del derecho de obligaciones formulada por la Comisión General de Codificación), en Revista de Derecho Privado, 104 (2010) 11-12.

García Rubio, María Paz, La responsabilidad precontractual en la propuesta de modificación del derecho de obligaciones y contratos, en Anuario de Derecho Civil, 63 (2010) 4 .

GómEZ LIGÜERRE, Carlos, El nuevo régimen de la morosidad en las obligaciones comerciales, en InDret, 4 (2011). 
Gómez Pomar, Fernando, El incumplimiento contractual en el derecho español, en InDret, 3 (2007).

IllesCas OrTIZ, Rafael, Lo que cambia en el derecho del transporte internacional tras las Reglas de Rotterdam, en Gómez SEgade, José Antonio - García Vidal, Ángel (editores), El Derecho mercantil en el umbral del siglo XXI. Libro Homenaje al Prof. Dr. Carlos Fernández-Novoa en su octogésimo cumpleaños (Madrid, Marcial Pons Ediciones Jurídicas y Sociales, 2010).

Illescas Ortiz, Rafael, Un nuevo Código de Comercio para España, en Derecho de los Negocios, 196 (2007).

IRti, Natalino, Scambi senza accordo, en Rivista Trimestrale di Diritto e Procedura Civile, 52 (1998).

Jerez Delgado, Carmen - Pérez García, Máximo Juan, La Comisión General de Codificación y su labor en la modernización del Derecho de obligaciones, en Revista Jurídica de la Universidad Autónoma de Madrid, 19 (2009) 1.

Marín García, Ignacio, La cláusula penal en la Propuesta de modernización del Código Civil en materia de obligaciones y contratos, en InDret, 4 (2009).

Martín Rodríguez, María Ángeles, La unificación civily mercantil en la contratación privada (Madrid, Editorial universitaria Ramón Areces, 2006).

Martínez Sanz, Fernando, ¿Derecho contractual europeo y dualidad Código CivilCódigo de Comercio? en Bosch Capdevilla, Esteve (director), Derecho contractual europeo. Problemática, propuestas y perspectivas (Barcelona, Editorial Bosch, 2009).

Menéndez Menéndez, Aurelio, Notas a propósito de la codificación mercantil, en Llamas Pombo, Eugenio (coordinador), Estudios de Derecho de obligaciones en homenaje al Profesor Mariano Alonso Pérez (Madrid, Editorial La Ley, 2006), II.

Miranda Serrano, Luis María, La contratación mercantil en general: su actual fisonomía y otras cuestiones preliminares, en Olivencia, Manuel - FernándeZ-NovoA, Carlos - Jiménez de PARga, Rafael (directores), Tratado de Derecho mercantil, XXX: La contratación mercantil. Disposiciones generales. Protección de los consumidores (Madrid, Marcial Pons Ediciones Jurídicas y Sociales, 2006).

Miranda Serrano, Luis María, Las disposiciones del Código de Comercio sobre el contrato y la obligación mercantil en general, en OLIVENCIA, Manuel - FERnÁndeZNovoa, Carlos - Jiménez de Parga, Rafael (directores), Tratado de derecho mercantil, XXX: La contratación mercantil. Disposiciones generales. Protección de los consumidores (Madrid, Marcial Pons Ediciones Jurídicas y Sociales, 2006).

Morales Moreno, Antonio Manuel, Adaptación del Código Civil al Derecho europeo: la compraventa (2003), ahora en La modernización del Derecho de obligaciones (Madrid, Editorial Thompson-Civitas, 2006).

Morales Moreno, Antonio Manuel, Evolución del concepto de obligación en el Derecho español (2005), ahora en El MISMO, La modernización del Derecho de obligaciones (Madrid, Editorial Thomson-Civitas, 2006).

Morales Moreno, Antonio Manuel, Problemas que plantea la unificación del concepto de incumplimiento contractual, en Barros Bourie, Enrique - García Rubio, María Paz - Morales Moreno, Antonio, Derecho de daños (Madrid, Fundación Coloquio Jurídico Europeo, 2009).

Olivencia Ruiz, Manuel, Un Código Mercantil del siglo XXI, en Gómez Segade, José Antoni - GARcía VIDAL, Ángel (editores), El Derecho mercantil en el umbral del siglo XXI. libro Homenaje al Prof. Dr. Carlos Fernández-Novoa en su octogésimo cumpleaños (Madrid, Marcial Pons Ediciones Jurídicas y Sociales, 2010). 
Pantaleón Prieto, Fernando, El sistema de responsabilidad contractual (materiales para un debate), en Anuario de Derecho Civil, 44 (1991) 3.Pantaleón Prieto, Fernando, Incumplimiento (D. Civil), en Enciclopedia Jurídica Básica (Madrid, Editorial Civitas, 1995), II.

Pantaleón Prieto, Fernando, Las nuevas bases de la responsabilidad contractual, en Anuario de Derecho Civil, 46 (1993) 4.

Pinochet Olave, Ruperto, ¿Integra el derecho de consumo el derecho civil, el derecho mercantil o conforma una disciplina jurídica autónoma? en GUZMÁN BRITO, Alejandro (editor), Estudios de Derecho civil (Santiago, LegalPublishing, 2008), III.

Rodríguez Marín, Concepción, La Propuesta de Anteproyecto de modernización del Código Civil en materia de obligaciones y contratos. Diferencias y similitudes con el cumplimiento, en Revista del Notariado, 76 (2010).

Rojo Álvarez-Manzaneda, Carmen, Reflexiones sobre la forma del contrato en la Propuesta del Anteproyecto de Ley de modernización del Código Civil en materia de derechos y obligaciones, en Actualidad Juridica Aranzadi, 785 (2009).

Salvador Coderch, Pablo, Alteración de circunstancias en el art. 1213 de la Propuesta de modernización del Código Civil en materia de obligaciones y contratos, en InDret, 4 (2009).

San Miguel Pradera, Lis Paula, La modernización del derecho de obligaciones y la resolución por incumplimientos en los ordenamientos españoly chileno, en DE LA MAZA Gazmuri, Ínigo (coordinador), Cuadernos de análisis jurídico. Colección Derecho privado, VII: El incumplimiento contractual. Nuevasperspectivas (Santiago, Ediciones de la Universidad Diego Portales, 2011) [en prensa].

San Miguel Pradera, Lis Paula, Resolución por incumplimiento y modalidades de ejercicio (Madrid, Colegio de Registradores de la Propiedad y Mercantiles de España, 2004).

Soler Presas, Ana, La valoración del daño en el contrato de compraventa (Pamplona, Editorial Aranzadi, 1998). TALLON, Denis, L'inexécution du contrat:pour une autre présentation, en Revue Trimestrielle de Droit Civil, 2 (1994).

Tapia Hermida, Alberto Javier, Propuesta de Código de Sociedades Mercantiles, en Revista de Derecho Bancario y Bursátil, 89 (2003).

Vicent Chuliá, Francisco, Las misiones del derecho mercantil en el siglo XXI, en GómEZ Segade, José Antonio - García VIdal, Ángel (editores), El Derecho mercantil en el umbral del siglo XXI. Libro Homenaje al Prof. Dr. Carlos Fernández-Novoa en su octogésimo cumpleaños (Madrid, Marcial Pons, 2010).

Vicent Chuliá, Francisco, Introducción al Derecho mercantil (21 a edición, Valencia, Editorial Tirant Lo Blanch, 2008).

Vidal Olivares, Álvaro, El incumplimiento y los remedios del acreedor en la Propuesta de modernización del derecho de obligaciones y contratos español, en Revista Chilena de Derecho Privado, 16 (2011).

Zweigert, Konrad - KöTZ, Hein, An Introduction to Comparative Law (traducción de Tony Weir, $3^{a}$ edición, Oxford, Oxford University Press, 1998). 